\title{
Overview of Environmental and Hydrogeologic Conditions at Lake Minchumina and Skwentna, Alaska
}

U.S. GEOLOGICAL SURVEY

Open-File Report 95-438

Prepared in cooperation with the

FEDERAL AVIATION ADMINISTRATION

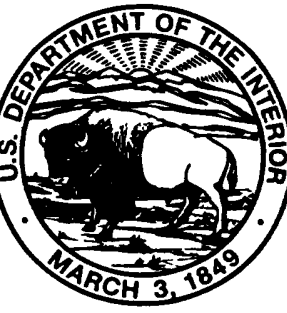




\section{Overview of Environmental and Hydrogeologic Conditions at Lake Minchumina and Skwentna, Alaska}

By James D. Hall

U.S. GEOLOGICAL SURVEY

Open-File Report 95-438

Prepared in cooperation with the

FEDERAL AVIATION ADMINISTRATION

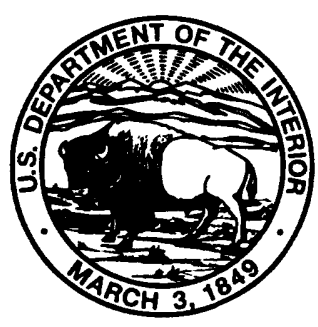

Anchorage, Alaska 


\title{
U.S. DEPARTMENT OF THE INTERIOR \\ BRUCE BABBITT, Secretary
}

\author{
U.S. GEOLOGICAL SURVEY
}

Gordon P. Eaton, Director

For additional information write to:

District Chief

U.S. Geological Survey 4230 University Drive, Suite 201

Anchorage, AK 99508-4664
Copies of this report may be purchased from:

U.S. Geological Survey

Earth Science Information Center

Open-File Reports Section

Box 25286, MS 517

Federal Center

Denver, CO 80225-0425 


\section{CONTENTS}

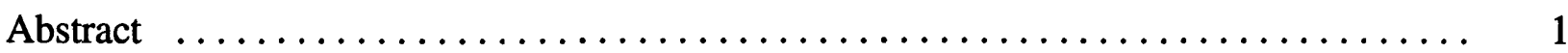

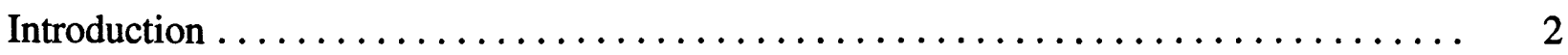

Lake Minchumina $\ldots \ldots \ldots \ldots \ldots \ldots \ldots \ldots \ldots \ldots \ldots \ldots \ldots \ldots \ldots \ldots \ldots \ldots, 2$

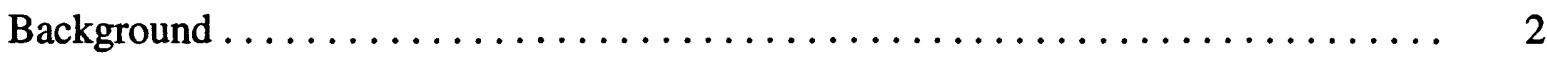

History and socioeconomics $\ldots \ldots \ldots \ldots \ldots \ldots \ldots \ldots \ldots \ldots \ldots \ldots, 2$

Climate ....................................... 2

Vegetation $. . \ldots \ldots \ldots \ldots \ldots \ldots \ldots \ldots \ldots \ldots \ldots \ldots \ldots \ldots \ldots \ldots, 4$

Geology ..................................... 5

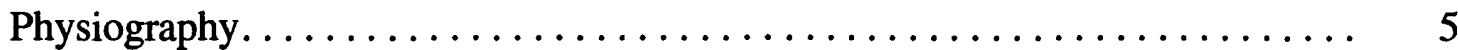

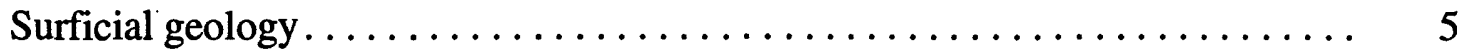

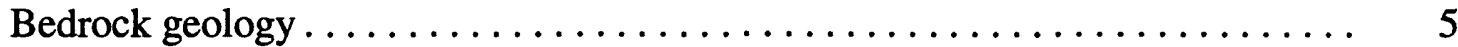

Hydrology $\ldots \ldots \ldots \ldots \ldots \ldots \ldots \ldots \ldots \ldots \ldots \ldots \ldots \ldots \ldots \ldots \ldots \ldots \ldots \ldots \ldots \ldots, 6$

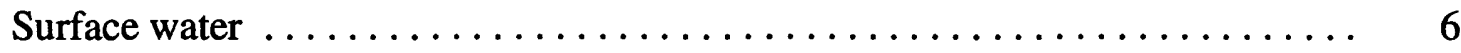

Floods ........................................ 6

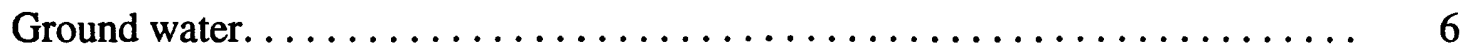

Drinking-water sources........................... 7

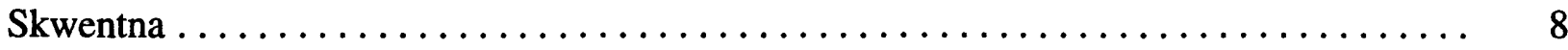

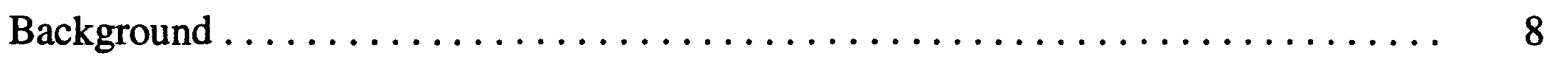

History and socioeconomics $\ldots \ldots \ldots \ldots \ldots \ldots \ldots \ldots \ldots \ldots \ldots \ldots \ldots, 8$

Climate .................................... 8

Vegetation.............................. 8

Geology ................................... 10

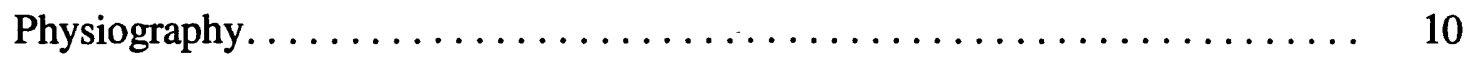

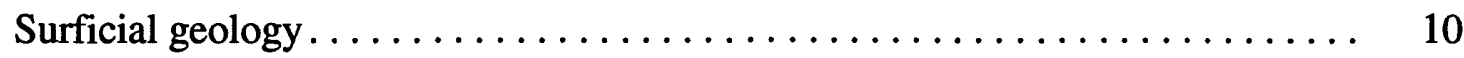

Bedrock geology $\ldots \ldots \ldots \ldots \ldots \ldots \ldots \ldots \ldots \ldots \ldots \ldots \ldots \ldots, 12$

Hydrology $\ldots \ldots \ldots \ldots \ldots \ldots \ldots \ldots \ldots \ldots \ldots \ldots \ldots \ldots \ldots \ldots \ldots \ldots \ldots \ldots \ldots \ldots, 12$

Surface water $\ldots \ldots \ldots \ldots \ldots \ldots \ldots \ldots \ldots \ldots \ldots \ldots \ldots \ldots \ldots \ldots \ldots \ldots \ldots, 12$

Floods ........................................... 13

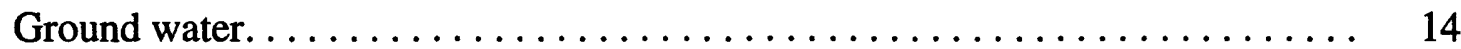

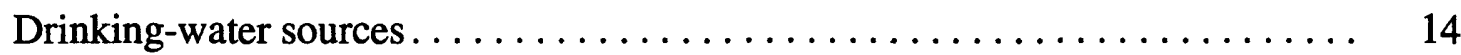

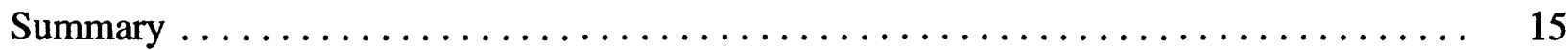

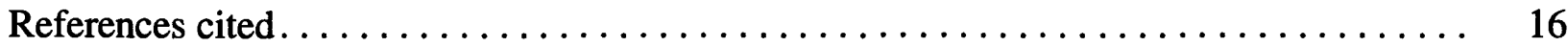

Appendix 1. Analyses of water from three wells at the Lake Minchumina

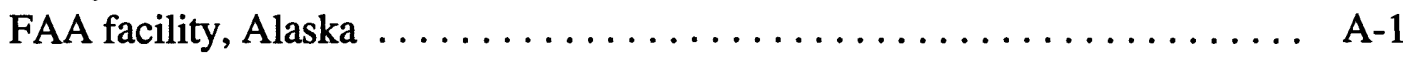

Appendix 2. Water record for a well at the Skwentna School $\ldots \ldots \ldots \ldots \ldots \ldots \ldots$ A-2 


\section{FIGURES}

1. Map showing the location of Lake Minchumina, Alaska, and the Federal Aviation

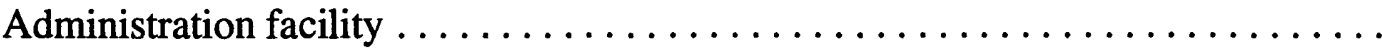

2. Map showing the location of Skwentna, Alaska, and the Federal Aviation Administration facility $\ldots \ldots \ldots \ldots \ldots \ldots \ldots \ldots \ldots \ldots \ldots \ldots \ldots \ldots \ldots \ldots$

3. Hydrograph showing mean daily discharge during the 1982 water year at USGS streamflow-gaging station 15294300, Skwentna River near

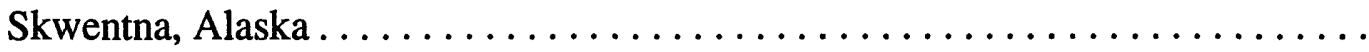

\section{TABLES}

1. Mean monthly and annual temperature, precipitation, and snowfall for the period 1967 to1987, Lake Minchumina, Alaska . . . . . . . . . . . . . . . . . 4

2. Water-quality data from wells at the Lake Minchumina FAA facility, Alaska .... 7

3. Mean monthly and annual temperature, precipitation, and snowfall for the period 1951 to 1987 , Skwentna, Alaska . . . . . . . . . . . . . . . . . . . . 10

4. Concentrations of selected elements from eight sediment samples within 10 kilometers of the Skwentna FAA facility near Skwentna, Alaska. .......... 11

5. Monthly mean flow at USGS streamflow-gaging station 15294300, Skwentna River near Skwentna, Alaska, water years $1960-82 \ldots \ldots \ldots \ldots \ldots \ldots \ldots \ldots \ldots$

6. Peak discharges of the Skwentna River for various recurrence intervals. ....... 14

7. Water-quality data from nine surface-water samples taken within 10 kilometers of the Skwentna FAA facility near Skwentna, Alaska ................ 15 


\section{CONVERSION FACTORS, VERTICAL DATUM, AND ABBREVIATED SOIL AND WATER-QUALITY UNITS}

\begin{tabular}{rll}
\hline Multiply & By & To obtain \\
millimeter $(\mathrm{mm})$ & 0.03937 & inch \\
meter $(\mathrm{m})$ & 3.281 & foot \\
kilometer $(\mathrm{km})$ & 0.6214 & mile \\
square kilometer $\left(\mathrm{km}^{2}\right)$ & 0.3861 & square mile \\
meter per kilometer $\left(\mathrm{m} / \mathrm{km}^{2}\right)$ & 5.28 & foot per mile \\
liter per second $(\mathrm{L} / \mathrm{s})$ & 15.85 & gallon per minute \\
cubic meter per second $\left(\mathrm{m}^{3} / \mathrm{s}\right)$ & 35.31 & cubic foot per second \\
cubic meter per second per square kilometer & 91.49 & cubic foot per second per square mile \\
{$\left[\left(\mathrm{m}^{3} / \mathrm{s}\right) / \mathrm{km}^{2}\right]$} & & \\
degree Celsius $\left({ }^{\circ} \mathrm{C}\right)$ & ${ }^{\circ} \mathrm{F}=1.8 \times{ }^{\circ} \mathrm{C}+32$ & degree Fahrenheit $\left({ }^{\circ} \mathrm{F}\right)$ \\
\hline
\end{tabular}

Sea level:

In this report "sea level" refers to the National Geodetic Vertical Datum of 1929--a geodetic datum derived from a general adjustment of the first-order level nets of both the United States and Canada, formerly called Sea Level Datum of 1929.

\section{Abbreviated soil and water-quality units used in this report:}

Chemical concentration and water temperature are given only in metric units. Chemical concentration in soil is given in milligrams per kilogram (mg/kg). Milligrams per kilogram is a unit expressing the mass per unit volume (kilogram) of soil. For concentrations less than 7,000 milligrams per kilogram, the numerical value is about the same as for concentrations in parts per million. Chemical concentration in water is given in milligrams per liter $(\mathrm{mg} / \mathrm{L})$ or micrograms per liter $(\mu \mathrm{g} / \mathrm{L})$. Milligrams per liter is a unit expressing the solute mass per unit volume (liter) of water. One thousand micrograms per liter is equivalent to 1 milligram per liter. For concentrations less than 7,000 milligrams per liter, the numerical value is about the same as for concentrations in parts per million. Specific conductance is given in microsiemens per centimeter at 25 degrees Celsius $\left(\mu \mathrm{S} / \mathrm{cm}\right.$ at $\left.25^{\circ} \mathrm{C}\right)$. 


\title{
Overview of Environmental and Hydrogeologic Conditions at Lake Minchumina and Skwentna, Alaska
}

\author{
By James D. Hall
}

\section{ABSTRACT}

The Federal Aviation Administration is conducting preliminary environmental assessments at most of its present or former facilities in Alaska. Two of these locations are at Lake Minchumina and Skwentna, Alaska. These locations were developed during 1942 and 1943, respectively, as part of the World War II buildup in defense of Alaska. Lake Minchumina and Skwentna are in remote areas of Alaska and are accessible primarily by air transportation because no roads connect these areas to the rest of Alaska. Alternative access is available to both locations by overland winter travel such as by snowmobile or dogsled. Alternative summer access is available to Skwentna by shallow-draft river boat.

Lake Minchumina is in the interior of Alaska within the Tanana-Kuskokwim Lowland. The region surrounding Lake Minchumina has a continental climate with warm summers and cold winters. The waters of Lake Minchumina create a local lake effect that moderates fluctuations in climatic conditions, such as daily temperature and the length of the no-frost season. Vegetation supported by this climate includes coniferous hardwood forest, white and black spruce, as well as areas of tamarack, willow, sedges, and grasses. This vegetation grows primarily on surficial deposits of Quaternary age sand and silt, which overlie metamorphic bedrock.

Lake Minchumina is the dominant hydrologic feature of the area. The lake is shallow and is fed by glacial and nonglacial streams. Ground water is abundant near Lake Minchumina and is the primary source of drinking water for the Federal Aviation Administration facility. Aquifer boundaries and directions of ground-water flow are poorly defined because of a lack of data. Ground water is likely affected by the presence of permafrost.

Skwentna is in south-central Alaska within the Cook Inlet-Susitna Lowland. The climate near Skwentna is transitional between maritime and continental, with cool summers and moderately cold winters. Vegetation supported by this climate is primarily spruce hardwood forest with willow, sedges, and grasses in open areas. This vegetation grows primarily in glacial or alluvial sediments overlying marine sedimentary bedrock.

The Skwentna Federal Aviation Administration facility and the village of Skwentna are near the confluence of the Skwentna and Yentna Rivers. These two rivers are primarily fed by glacier runoff and have braided channels. They generally have a high sediment load and commonly erode their banks, laterally changing course. There are numerous shallow morainal lakes nearby as well as areas of swampy muskeg. The availability of ground water is undefined but likely is abundant in the surficial sediments. Ground water is the primary source of drinking water. 


\section{INTRODUCTION}

The Federal Aviation Administration (FAA) owns and (or) operates airway support and navigational facilities throughout Alaska. At many of these sites, fuels and potentially hazardous materials such as solvents, polychlorinated biphenyls, and pesticides may have been used and (or) disposed of. To determine if environmentally hazardous materials have been spilled or disposed of at the sites, the FAA is conducting environmental studies mandated under the Comprehensive Environmental Response, Compensation, and Liability Act (CERCLA) and the Resource Conservation and Recovery Act (RCRA). To complete these more comprehensive environmental studies, the FAA requires information on the hydrology and geology of areas surrounding the sites. This report, the product of compilation, review, and summary of existing hydrologic and geologic data by the U.S. Geological Survey (USGS) in cooperation with the FAA, describes general groundwater conditions, flood hazards, and other environmental conditions for the FAA facilities and nearby areas at Lake Minchumina and Skwentna, Alaska.

\section{LAKE MINCHUMINA}

\section{Background}

Lake Minchumina (fig. 1) is in interior Alaska on the northwest edge of the TananaKuskokwim Lowland about $100 \mathrm{~km}$ northwest of Mount McKinley, the tallest mountain on the North American Continent (Wahrhaftig, 1965). The Lake Minchumina FAA facility lies on the northwestern shore of Lake Minchumina at lat $63^{\circ} 53^{\prime} \mathrm{N}$., long $152^{\circ} 17^{\prime} \mathrm{W}$. and at an elevation of about $208 \mathrm{~m}$ (National Oceanic and Atmospheric Administration, 1993). Access to the area is limited to air traffic because no roads connect Lake Minchumina to other areas of Alaska. Alternative access, such as by dogsled or snowmobile, is available over winter trails. A detailed description of the Lake Minchumina FAA facility is given in an RCRA Facility Investigation Corrective Measures Study by Ecology and Environment, Inc. (1992a).

\section{History and Socioeconomics}

The Lake Minchumina FAA facility was built in 1942 as a part of the World War II defense buildup in Alaska and remained in operation until 1969 (Holmes and Gudgel-Holmes, 1988). Since then, it has been used as a public recreation and emergency landing strip, a staging base for military maneuvers, and more commonly a U.S. Bureau of Land Management forest-fire-fighting base (Holmes and Gudgel-Holmes, 1988). It presently consists of two intersecting unattended gravel airstrips, an operating remote communications outlet, and additional support buildings (Ecology and Environment Inc., 1992a; National Oceanic and Atmospheric Administration, 1993). In 1990, the population of Lake Minchumina was 32, of which six were American Indian, Eskimo, or Aleut (U.S. Census Bureau, 1991).

\section{Climate}

Lake Minchumina has a modified continental climate (Hartman and Johnson, 1984; Kodama, 1981 ; table 1). The region has warm summers and cold winters typical of a continental climate. However, Lake Minchumina creates a lake effect that modifies the climate within about a 6-km radius of the lakeshore (Kodama, 1981). Within this radius, daily air temperature fluctuates less 

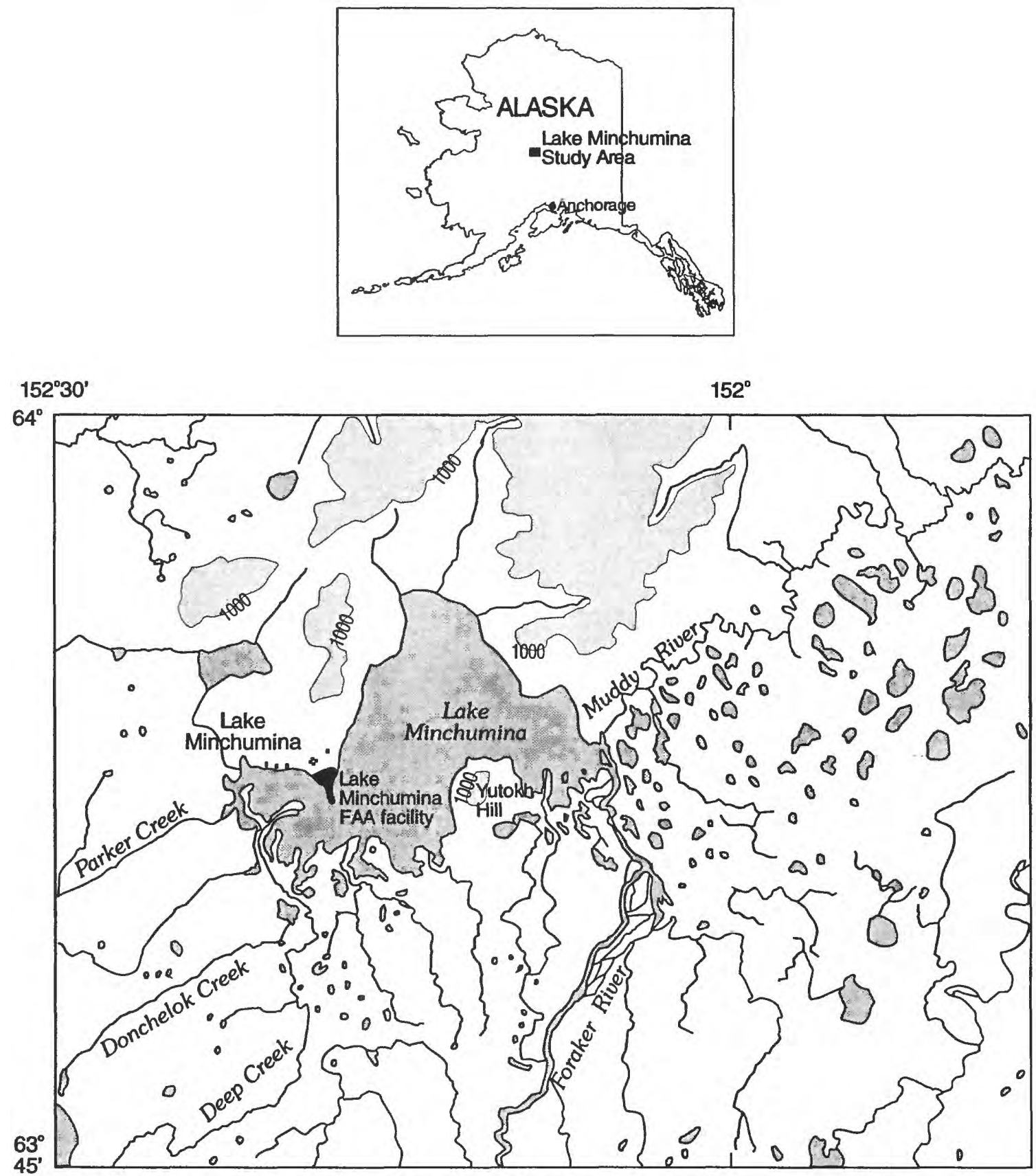

Base from U.S.Geological Survey, Mt. McKinley, Alaska, 1:250,000, 1958

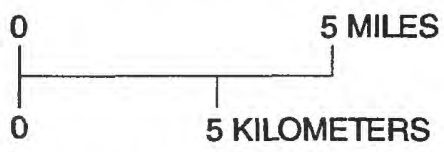

CONTOUR INTERVAL (SHADED) IN FEET

Figure 1. Location of Lake Minchumina, Alaska and the Federal Aviation Administration facility. 
than in nearby areas with an unmodified continental climate, and the period between the last spring frost and the first fall frost is extended (Kodama, 1981).

A weather station was operated at the Lake Minchumina FAA facility between 1967 and 1987. This station operated within the "lake effect" zone identified by Kodama (1981). The mean annual temperature is $-2.8^{\circ} \mathrm{C}$ and temperatures range from a July mean maximum of $21.9^{\circ} \mathrm{C}$ to a February mean minimum of $-24.2^{\circ} \mathrm{C}$ (Leslie, 1989). Mean annual precipitation is about $320 \mathrm{~mm}$; about $1,330 \mathrm{~mm}$ of snow falls annually (Leslie, 1989). Mean monthly and annual temperature, precipitation, and snowfall are summarized in table 1.

Table 1. Mean monthly and annual temperature, precipitation, and snowfall for the period 1967 to 1987 , Lake Minchumina, Alaska

[Modified from Leslie (1989); ${ }^{\circ} \mathrm{C}$, degree Celsius; mm, millimeter]

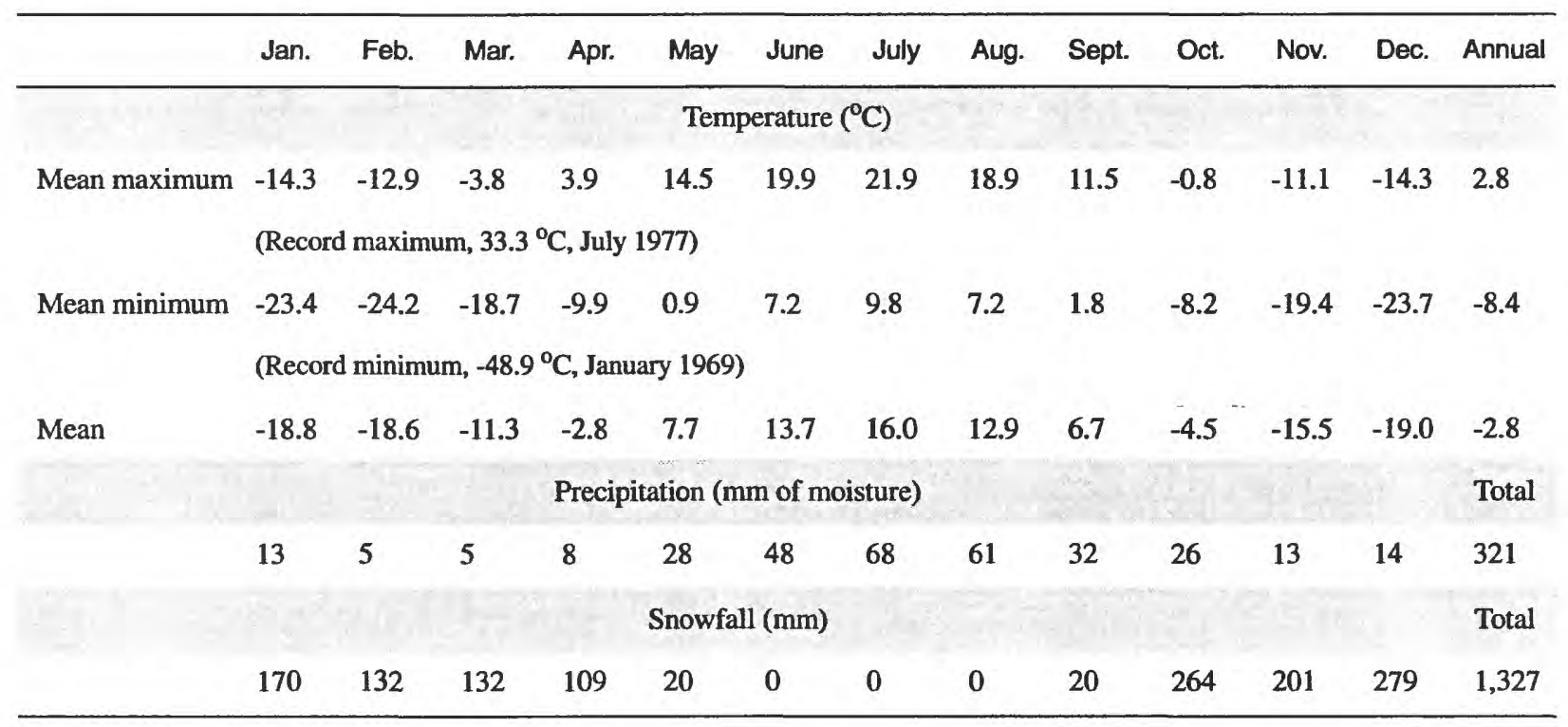

\section{Vegetation}

Vegetation near Lake Minchumina is dominated by coniferous hardwood forest and white and black spruce (Viereck and Little, 1972). Stands of paper birch, as well as aspen and balsam poplar grow in moderately well-drained locations (Kodama, 1981; Viereck and Little, 1972). In wetter areas, the forest canopy opens, allowing the intrusion of tamarack, willow, sedges, and grasses (Viereck and Little, 1972). On the eastern and western sides of the lake, sedges and grasses catch silt and organics from tributary streams and form a treeless boggy area (Kodama, 1981). Aerial photographs indicate that vegetation near the Lake Minchumina FAA facility consists of sparsely forested areas to the south and more densely forested areas to the north. 


\section{Geology}

\section{Physiography}

Lake Minchumina is at the northern edge of a broad plain which extends as the TananaKuskokwim Lowland from the base of the Kuskokwim Mountains (Wahrhaftig, 1965). The foothills of the Kuskokwim Mountains rise to the northwest of the runways on the northern shore of Lake Minchumina, providing local topographic relief. Additional relief is provided by Yutokh Hill, a peninsula extending north into Lake Minchumina from the southern shore. South of the Lake Minchumina FAA facility, a gravel spit extends into Lake Minchumina.

Lake Minchumina has formed in the topographic low between the bedrock foothills along the northern and western shores and the rapidly aggrading Foraker River delta on the southern and eastern shores. Lake Minchumina and the Foraker/Muddy Rivers wetlands at the east side of Lake Minchumina are sediment traps, where sediment-rich outwash of the Foraker River has deposited its sediment load in low-velocity lacustrine and palustrine waters. The palustrine deposit at the east end of Lake Minchumina is "accumulating rapidly" (Reed, 1961). Fine-grained palustrine and lacustrine deposits are less capable of conducting ground water than are the coarser outwash deposits of the Foraker River delta. Fine-grained sediments are also more likely to contain permafrost.

\section{Surficial Geology}

Surficial deposits near Lake Minchumina consist primarily of sand and silt of Quaternary age with local minor deposits of gravel and peat (Anderson, 1970). To the east, deposits are eolian, forming linear and parabolic sand dunes (Anderson, 1970). To the south, surficial deposits are well stratified to lenticular sand and may contain discontinuous permafrost (Anderson, 1970). In the hills to the northeast of the FAA facility, surficial deposits are poorly sorted to well-sorted sand and gravel, include peat, and are likely to contain permafrost (Anderson, 1970). At the Lake Minchumina FAA facility, up to $10 \mathrm{~m}$ of rubble talus and colluvium cover bedrock (Anderson, 1970; Martinson, 1982; Ondra, 1988). A layer of organic material about $0.5 \mathrm{~m}$ thick overlies those unconsolidated sediments (Martinson, 1982; Ondra, 1988).

Permafrost is found in the area surrounding the Lake Minchumina FAA facility (Ferrians, 1965). Test holes drilled into the east-west runway revealed ice at a depth of about $1.5 \mathrm{~m}$ (Martinson, 1982). Martinson surmised that this depth is the base of the active layer of the soil and the top of the permafrost.

\section{Bedrock Geology}

Reed (1961) described metamorphic bedrock exposed on the hills along the northern shore of Lake Minchumina as "dark- to medium-gray silicious shale and gray and brown massive to thinbedded chert with some chert breccia, large amounts of massive gray quartzite, and finely laminated flaggy sandstone." Martinson (1982), and Ondra (1988) subsequently identified volcanic tuff interbedded with layers of chert in a borrow pit less than $1 \mathrm{~km}$ northwest of the Lake Minchumina runways. A major northwest-trending anticline is exposed northeast of the lake in the foothills of the Kuskokwim Mountains (Reed, 1961).

In 1987, the Alaska Department of Transportation and Public Facilities conducted a study of the engineering geology and soils of the Lake Minchumina FAA facility (Ondra, 1988). About 140 test holes were drilled to depths ranging between 5 and $10 \mathrm{~m}$. Depth to bedrock ranged from less than $1 \mathrm{~m}$ to greater than $10 \mathrm{~m}$. 


\section{HYDROLOGY}

\section{Surface Water}

Lake Minchumina is the dominant surface-water body near the Lake Minchumina FAA facility. The lake has a surface area of about $65 \mathrm{~km}^{2}$ and a maximum depth of about $12 \mathrm{~m}$ (Kodama, 1981). Numerous streams supply Lake Minchumina: the largest tributary is the Foraker River to the southeast. Other tributaries enter the lake from the south and west. Lake Minchumina is drained by the Muddy River, which flows east from the eastern shore of the lake less than $1 \mathrm{~km}$ north of the mouth of the Foraker River.

Despite an abundance of lakes and streams near Lake Minchumina, hydrologic data are sparse. The streams and lakes near Lake Minchumina are fed by a combination of rain, snowmelt, and glacial melt, as well as ground-water flow. The Foraker River receives glacial runoff from the Alaska Range, about $60 \mathrm{~km}$ to the south, and the suspended-sediment load of the river is higher than that of nonglacial streams in the area. The primary drainage out of the area surrounding Lake Minchumina is the Muddy River.

\section{Floods}

Floods at the Lake Minchumina FAA facility have been caused by blockages of the Muddy River as a result of ice jams and sediment deposition. Holmes and Gudgel-Holmes (1988) note that floods were a common event on the lower runway of the Lake Minchumina FAA facility prior to 1952. In 1952, the Foraker River cut a new channel into the eastern shore of Lake Minchumina near the outlet of the Muddy River, subsequently causing the water level of the lake to decline (Holmes and Gudgel-Holmes, 1988). They report that, consequently, only one flood occurred during the period 1953-88. Floods could also result from a sudden release of water from an ice jam on the Foraker River or other tributary stream, but such floods have not been recorded.

\section{Ground Water}

Anderson (1970) reported that ground water in the region around Lake Minchumina is abundant and likely available in quantities greater than $3 \mathrm{~L} / \mathrm{s}$ (Anderson, 1970). Anderson did not, however have the test-hole data that are now available. Ondra (1988) identified bedrock at depths of less than $10 \mathrm{~m}$ at the Lake Minchumina FAA facility. Yields of water from bedrock are likely to be less than those predicted by Anderson. Depth to the water table is between $10 \mathrm{~m}$ and $65 \mathrm{~m}$ and is likely to be at approximately the elevation of the lake surface.

The direction of ground-water flow can be predicted with some confidence in the area south of Lake Minchumina, where ground water flows downgradient through the outwash gravels of the delta into Lake Minchumina. At the FAA facilities, however, the peninsula is surrounded by the flat lake surface. If the lake level remained constant, this would cause the local water table to be flat and rates of ground-water flow to be slow. The lake level is not steady however. Instead, it rises during the summer melt season and falls throughout the winter. Ground water is likely to move into and out of the lake as the stage of the lake rises and falls. This will create a highly transient system in which directions of ground-water flow can change by 180 degrees. 


\section{Drinking-Water Sources}

Ground water is likely the primary source of drinking water for the Lake Minchumina FAA facility and bedrock underlying the facility is likely the primary aquifer. This premise is based on the depth of the wells, the depth to bedrock, and the depth of one water level measured at about $50 \mathrm{~m}$ below land surface (appendix 1). Residents near Lake Minchumina may obtain drinking water from bedrock wells, shallow wells, streams, or lakes such as Lake Minchumina. However, the data are inadequate to characterize the quantity or quality of these sources. Recent cleanup activities have reduced the risk to the water supply from FAA activities.

Three FAA-owned wells provide drinking water for the Lake Minchumina FAA facility (appendix 1). Water-quality data from the three wells are shown in table 2. The concentrations of those constituents analyzed are below levels set by the U.S. Environmental Protection Agency (1995).

Table 2. Water-quality data from wells at the Lake Minchumina FAA facility, Alaska

[Data in milligrams per liter except where indicated; $\mu \mathrm{S} / \mathrm{cm}$, microsiemens per centimeter at $25^{\circ} \mathrm{C}$ ]

\begin{tabular}{lcccc}
\hline $\begin{array}{c}\text { Constituent } \\
\text { (or property) }\end{array}$ & USEPA regulation & New well & Duplex well & Well No. 3 \\
\hline Sulfate $\left(\mathrm{SO}_{4}\right)$ & $250^{\mathrm{b}}$ & 17 & 23 & 20 \\
Fluoride (F) & $2.0^{\mathrm{c}}$ & 0.1 & 0.0 & 0.2 \\
Chloride (Cl) & $250^{\mathrm{d}}$ & 2.0 & 2.0 & 2.0 \\
Iron (dissolved; Fe) & $0.3^{\mathrm{d}}$ & 0.02 & 0.03 & 0.10 \\
Total dissolved solids & $500^{\mathrm{d}}$ & 117 & 130 & 121 \\
pH (units) & $6.5-8.5^{\mathrm{d}}$ & 8.1 & 6.7 & 7.0 \\
Specific conductance & - & 206 & 228 & 207 \\
$(\mu \mathrm{S} / \mathrm{cm})$ & & & & \\
\hline
\end{tabular}

${ }^{\mathrm{a}}$ From U.S. Environmental Protection Agency (1995).

${ }^{b}$ Maximum contaminant level.

${ }^{c}$ Maximum contaminant level-under review.

${ }^{\mathrm{d} S e c o n d a r y}$ maximum contaminant level. 


\section{SKWENTNA}

\section{Background}

The village of Skwentna is in south-central Alaska near lat $61^{\circ} 58^{\prime} \mathrm{N}$., long $151^{\circ} 11^{\prime} \mathrm{W}$. (fig. 2). The Skwentna Airport and FAA facility are on the north bank of the Skwentna River (fig. 2) in the northern Cook Inlet-Susitna Lowland (Wahrhaftig, 1965). The facility is about $1 \mathrm{~km}$ north of the village of Skwentna, $3 \mathrm{~km}$ west of the confluence of the Skwentna and Yentna Rivers, and about $100 \mathrm{~km}$ from Anchorage. The Skwentna FAA facility is at an elevation of about $45 \mathrm{~m}$ (National Oceanic and Atmospheric Administration, 1993). Access to the area is limited to air traffic, shallow-draft river-boat and barge travel during summer months. In winter, the area is also accessible by snowmobile and dogsled. A detailed description of the Skwentna FAA facility is given in an Environmental Compliance Investigation Report by Ecology and Environment, Inc. (1992b).

\section{History and Socioeconomics}

The Skwentna FAA facility was originally built in 1943 as a part of the World War II buildup in defense of Alaska. The facility consists of one unattended runway, a non-directional beacon, and additional unmaintained support buildings (National Oceanic and Atmospheric Administration, 1993). The population of the village of Skwentna in 1990 was 85 , of whom approximately 1 percent were American Indian, Eskimo, or Aleut (U.S. Census Bureau, 1991). About one-third of the population is employed, with jobs split nearly evenly between local government and private employment (Alaska Department of Community and Regional Affairs, 1991). The FAA provides no on-site employment at Skwentna.

\section{Climate}

Skwentna has a climate that is transitional between maritime and continental (Hartman and Johnson, 1984). The region experiences cool summers and moderately cold winters. The mean annual temperature is $0.2{ }^{\circ} \mathrm{C}$, but temperatures range from a July mean maximum of $20.8^{\circ} \mathrm{C}$ to a January mean minimum of $-19.1^{\circ} \mathrm{C}$ (Leslie, 1989). Mean annual precipitation is about $720 \mathrm{~mm}$; about $2,900 \mathrm{~mm}$ of snow falls annually (Leslie, 1989). Mean monthly and annual temperature, precipitation, and snowfall are summarized in table 3.

\section{Vegetation}

Vegetation near Skwentna is composed of spruce hardwood forest (Viereck and Little, 1972; Selkregg, 1976). The forest primarily contains white spruce, Alaska paper birch, quaking aspen, black cottonwood, and balsam poplar with willow, sedges, and grasses in open areas (Selkregg, 1976). The area immediately surrounding the airport is densely forested. 

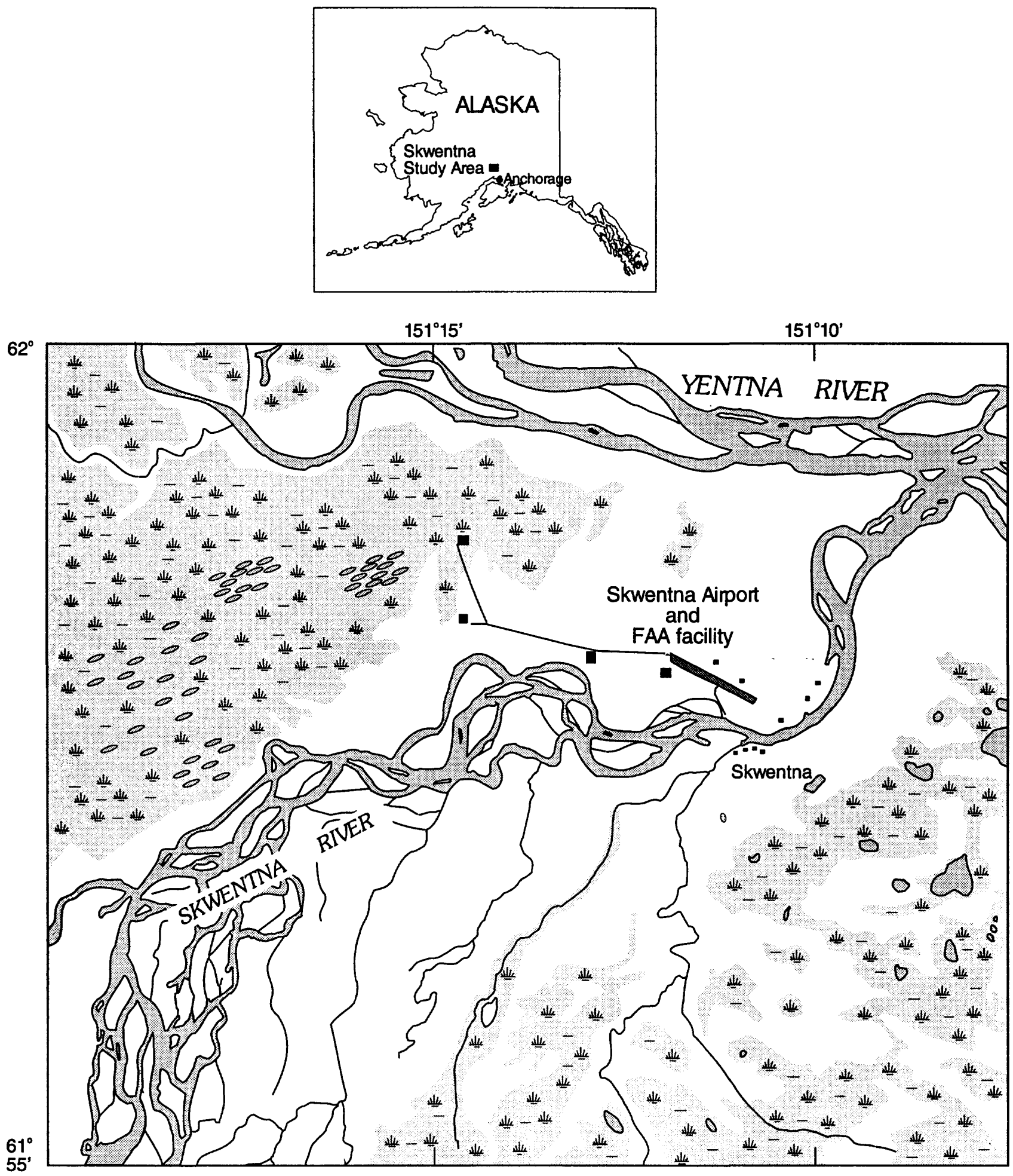

Base from U.S.Geological Survey, Tyonek (D-4), Alaska, 1:63,360, 1951

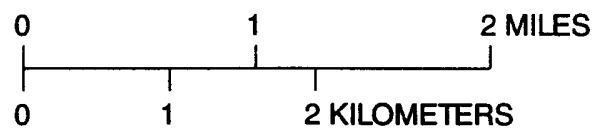

Figure 2. Location of Skwentna, Alaska and the Federal Aviation Administration facility. 
Table 3. Mean monthly and annual temperature, precipitation, and snowfall for the period 1951 to 1987 , Skwentna, Alaska

[Modified from Leslie (1989); ${ }^{\circ} \mathrm{C}$, degree Celsius; mm, millimeter]

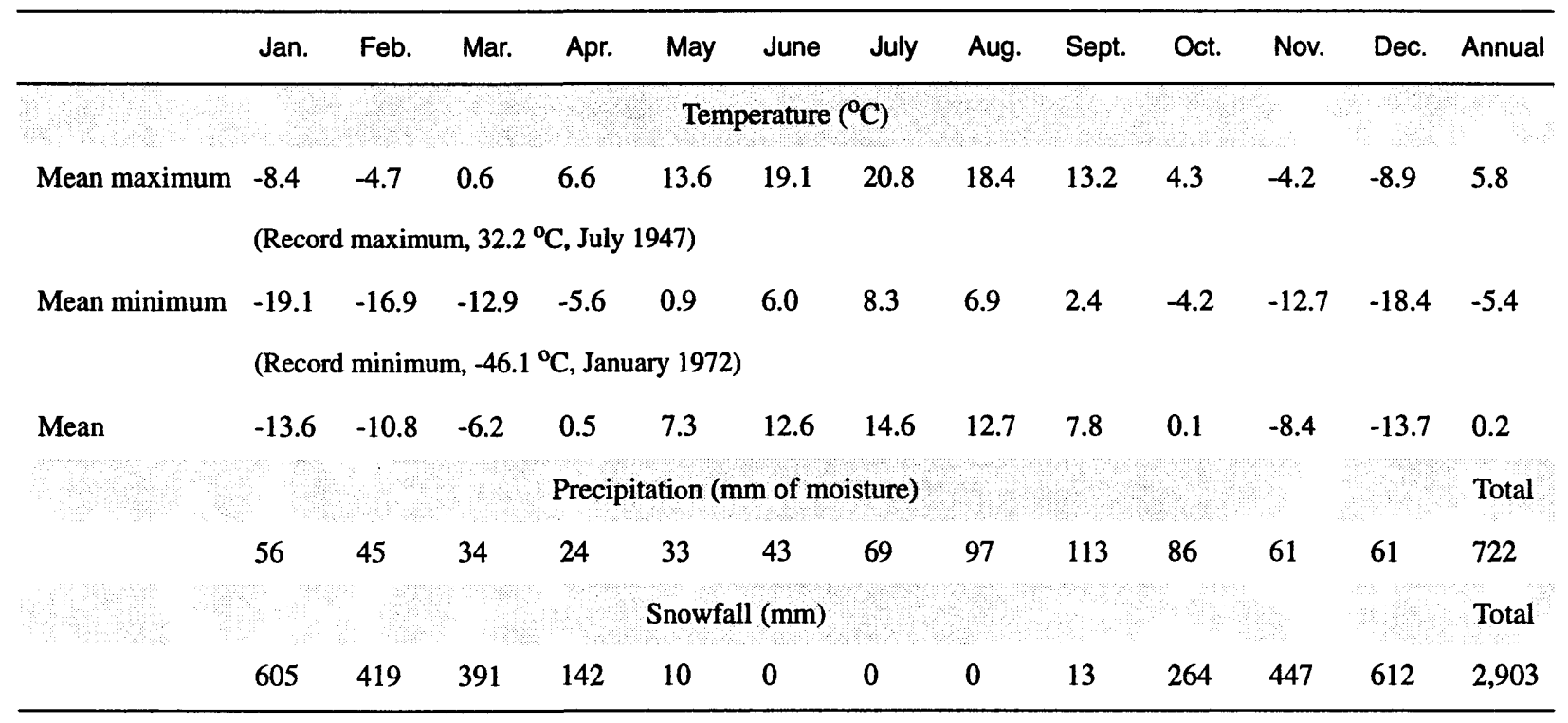

\section{GEOLOGY}

\section{Physiography}

Skwentna lies on a stream terrace in a glaciated trough within the Cook Inlet-Susitna Lowland (Wahrhaftig, 1965). The trough is oriented in a northwest-southeast direction near Skwentna, and is about $15 \mathrm{~km}$ wide. The trough is bordered by the Yenlo Hills, about $5 \mathrm{~km}$ to the north, and the Shell Hills, about $10 \mathrm{~km}$ to the west of the Skwentna FAA facility. Glacial activity in this area originated in the Alaska Range about $30 \mathrm{~km}$ to the north and west of the FAA facility. The Cook Inlet-Susitna Lowland near Skwentna slopes gently to the south toward Cook Inlet, about $85 \mathrm{~km}$ away. The surrounding hills, mountains, and morainal deposits provide local relief.

\section{Surficial Geology}

Surficial sediments in the area surrounding Skwentna were deposited by glaciers and streams. Glacial drift is the primary deposit within the region and obscures most bedrock (Magoon and others, 1976; Reed and Nelson, 1980). Along streambanks, stream action has eroded the drift replacing it with alluvial deposits or exposed bedrock (Magoon and others, 1976; Reed and Nelson, 1980). Both the glacial drift and the alluvial deposits are derived from the bedrock of the Alaska Range. Along the Skwentna and Yentna Rivers and near the Skwentna FAA facility, surficial deposits are primarily alluvium that extends to an unknown depth. The surficial deposits in areas surrounding Skwentna are generally free of permafrost (Ferrians, 1965; Hopkins and others, 1955; Rieger and others, 1979).

The Alaska Department of Transportation and Public Facilities performed a materials investigation at the Skwentna FAA facility in October 1986 (Ottley, 1987). Fifty test holes were drilled to a depth of about $5 \mathrm{~m}$ to ascertain the composition of the airport foundation and to locate material which could be used as construction material for a proposed runway extension project. Logs of 
these test holes indicate that the surficial deposits consist of intermixed silt, sand, and gravel with sparse cobbles. Areas near the runway are overlain by a layer of less than $1 \mathrm{~m}$ of organic material intermixed with silt and sand. Test holes in the runway foundation had negligible amounts of organic material. Bedrock was not located by these test holes.

Eight sediment samples were collected within $10 \mathrm{~km}$ of the Skwentna FAA facility during a uranium reconnaissance of the Tyonek National Topographic Map Series (NTMS) quadrangle (Jacobsen and others, 1979). Analyses of these sediments identified the amount of uranium present as well as 43 additional elements (Jacobsen and others, 1979). These analyses provide base data for elemental concentrations of sediments near Skwentna, suggesting a range of normal concentrations for Skwentna and nearby areas. Concentrations of selected elements are summarized in table 4.

Table 4. Concentrations of selected elements from eight sediment samples within 10 kilometers of the Skwentna FAA facility near Skwentna, Alaska.

[Data in milligrams per kilogram; <, less than; - , data not available; data from Jacobsen and others (1979)]

\begin{tabular}{|c|c|c|c|c|c|c|c|c|}
\hline \multirow{2}{*}{ Element } & \multicolumn{8}{|c|}{ Sediment sample No. } \\
\hline & A49801 & A49802 & A49901 & A49936 & A49939 & A49986 & A49987 & A50056 \\
\hline Aluminum (Al) & 51,135 & 52,945 & 55,401 & 103,670 & 34,214 & 82,557 & 90,161 & 36,431 \\
\hline Antimony (Sb) & $<1$ & $<1$ & $<1$ & 2 & $<1$ & $<1$ & 2 & $<1$ \\
\hline Barium (Ba) & 599 & 423 & 504 & 634 & - & 931 & 539 & 310 \\
\hline Beryllium (Be) & $<1$ & 1 & $<1$ & $<1$ & 2 & 2 & 2 & $<1$ \\
\hline Cadmium (Cd) & $<5$ & $<5$ & - & $<5$ & $<5$ & $<5$ & $<5$ & $<5$ \\
\hline Calcium (Ca) & 9,205 & 9,205 & 7,054 & 37,553 & 8,625 & 13,590 & 17,710 & 11,535 \\
\hline Chromium (Cr) & 76 & 50 & 74 & 70 & 65 & 90 & 30 & 44 \\
\hline Cobalt (Co) & 13.6 & 14.0 & 11.3 & 11.2 & 17.1 & 12.8 & 10.1 & 11.7 \\
\hline Copper $(\mathrm{Cu})$ & 35 & 35 & - & 46 & 14 & 39 & 37 & 23 \\
\hline Iron $(\mathrm{Fe})$ & 21,673 & 16,050 & 22,680 & 39,936 & 19,431 & 36,585 & 41,294 & 13,780 \\
\hline Lead $(\mathrm{Pb})$ & 5 & 9 & - & 7 & $<5$ & 15 & 10 & $<5$ \\
\hline Magnesium (Mg) & 8,991 & 11,726 & 20,776 & 35,687 & - & 16,598 & 25,426 & 10,660 \\
\hline Manganese (Mn) & 1,258 & 384 & 343 & 1,092 & 278 & 438 & 858 & 232 \\
\hline Nickel (Ni) & 24 & 23 & - & 22 & $<15$ & 25 & $<15$ & $<15$ \\
\hline Potassium (K) & - & 13,009 & 13,276 & 17,616 & - & 18,785 & 28,334 & 5,099 \\
\hline Silver (Ag) & $<5$ & $<5$ & - & $<5$ & $<5$ & $<5$ & $<5$ & $<5$ \\
\hline Sodium (Na) & 14,632 & 13,793 & 12,060 & 34,704 & 8,370 & 16,623 & 32,075 & 9,429 \\
\hline Vanadium (V) & 59 & 79 & 83 & 178 & 52 & 124 & 104 & 58 \\
\hline Zinc (Zn) & 299 & 158 & 191 & 102 & 275 & 201 & - & 170 \\
\hline
\end{tabular}




\section{Bedrock Geology}

Bedrock near Skwentna is exposed on the slopes of hills and mountains and in riverbanks. Bedrock exposed in the Yenlo Hills consists of isoclinally folded marine sedimentary rocks such as graywacke containing plagioclase, volcanic rock fragments, hornblende, epidote, and calcite (Reed and Nelson, 1980). These sedimentary rocks are considered by Wolfe and others (1966) to be of Tertiary age on the basis of the fossil flora. Bedrock exposed in the Shell Hills consists of intrusive igneous rocks such as granite, quartz monzonite, and syenite (Reed and Nelson, 1980). Bedrock exposed in the banks of the Skwentna River, about $15 \mathrm{~km}$ to the southwest of the FAA facility, and on Beluga Mountain, about $20 \mathrm{~km}$ to the south of the FAA facility, consists of metamorphosed sedimentary rocks such as shale and graywacke (Reed and Nelson, 1980). One well, which was drilled for a public supply at the Skwentna school to a depth of about $11 \mathrm{~m}$, did not reach bedrock (appendix 2). Depth to bedrock in Skwentna and at the Skwentna FAA facility is unknown.

\section{HYDROLOGY}

\section{Surface Water}

Surface water near Skwentna is found in the Skwentna and Yentna Rivers, their many tributary streams, and in numerous small lakes and ponds. The Skwentna and Yentna Rivers have braided channels and glacier sources. They both originate from glaciers in the Alaska Range and generally have a higher sediment load than nonglacial streams. Aerial photographs of the Skwentna River show multiple meander scars and indicate main channel movement to the north from 1952 to 1992. The alluvium of the Skwentna and Yentna Rivers is in hydrologic or hydraulic contact with the less permeable glacial drift located along the sides of the trough. Morainal lakes in the drift are apparently in communication with ground water in the drift and less directly in communication with the alluvium.

The Skwentna River is the dominant surface-water body near Skwentna and the Skwentna FAA facility. The river has a main channel slope of about $6 \mathrm{~m} / \mathrm{km}$ and a drainage area of about $5,825 \mathrm{~km}^{2}$ upstream from the USGS streamflow-gaging station 15294300 , which is about $14 \mathrm{~km}$ southwest of the Skwentna FAA facility (Freethey and Scully, 1980; U.S. Geological Survey, 1995). This station was operated on the Skwentna River near Skwentna during water years 19601982 (U.S. Geological Survey, 1995). The annual unit runoff for the period of 1960-76 was $0.032\left(\mathrm{~m}^{3} / \mathrm{s}\right) / \mathrm{km}^{2}$ (Freethey and Scully, 1980). Monthly and annual statistics for the period of record are summarized in table 5; the year of record is given with the maximum and minimum discharge values.

Data from the 1982 water year provide information about the normal discharge distribution for the Skwentna River. Peak flows occur when rain and glacial meltwaters combine during the warmer summer months. Discharge during the period from June through August constitutes about 65 percent of the mean annual flow. Low flows occur during the cooler winter months when snow accumulated and glacial melt was at a minimum. The mean daily discharge values for the Skwentna River during the 1982 water year are plotted in figure 3 (U.S. Geological Survey, 1983). Nonglacial streams are common on the terrace in the vicinity of Skwentna, and have smaller discharges than the Skwentna River. 
Table 5. Monthly mean flow at USGS streamflow-gaging station 15294300, Skwentna River near Skwentna, Alaska, water years 1960-82

[Data in cubic meters per second]

\begin{tabular}{|c|c|c|c|c|c|c|c|c|c|c|c|c|c|}
\hline & Oct. & Nov. & Dec. & Jan. & eb. & Mar. & Apr. & May & June & July & Aug. & Sept. & Annual \\
\hline Mean & 128 & 55.1 & 3 & 31.7 & 27.0 & 23.7 & 31.0 & 244 & 538 & 500 & 0 & 2 & 187 \\
\hline $\begin{array}{l}\text { Monthly mean } \\
\text { maximum }\end{array}$ & $\begin{array}{l}205 \\
(1980)\end{array}$ & $\begin{array}{l}119 \\
(1980)\end{array}$ & $\begin{array}{l}81.3 \\
(1977)\end{array}$ & $\begin{array}{l}80.1 \\
(1977)\end{array}$ & $\begin{array}{l}51.6 \\
(1977)\end{array}$ & $\begin{array}{l}38.3 \\
(1980)\end{array}$ & $\begin{array}{l}60.5 \\
(1981)\end{array}$ & $\begin{array}{l}634 \\
(1981)\end{array}$ & $\begin{array}{l}1,040 \\
(1977)\end{array}$ & $\begin{array}{l}811 \\
(1980)\end{array}$ & $\begin{array}{l}571 \\
(1977)\end{array}$ & $\begin{array}{l}429 \\
(1982)\end{array}$ & $\begin{array}{l}285 \\
(1977)\end{array}$ \\
\hline $\begin{array}{c}\text { Monthly mean } \\
\text { minimum }\end{array}$ & $\begin{array}{l}54.6 \\
(1969)\end{array}$ & $\begin{array}{c}19.2 \\
(1969)\end{array}$ & $\begin{array}{l}17.7 \\
(1969)\end{array}$ & $\begin{array}{l}17.0 \\
(1969)\end{array}$ & $\begin{array}{l}17.0 \\
(1969)\end{array}$ & $\begin{array}{l}17.0 \\
(1964)\end{array}$ & $\begin{array}{l}17.2 \\
(1971)\end{array}$ & $\begin{array}{c}46.3 \\
(1964)\end{array}$ & $\begin{array}{l}302 \\
(1974)\end{array}$ & $\begin{array}{l}331 \\
(1974)\end{array}$ & $\begin{array}{l}212 \\
(1969)\end{array}$ & $\begin{array}{l}107 \\
(1969)\end{array}$ & $\begin{array}{l}146 \\
(1974)\end{array}$ \\
\hline
\end{tabular}

Highest daily mean. . . 1,440 (June 9, 1977)

Lowest daily mean. . . 17.0 (March 1,1964$)$

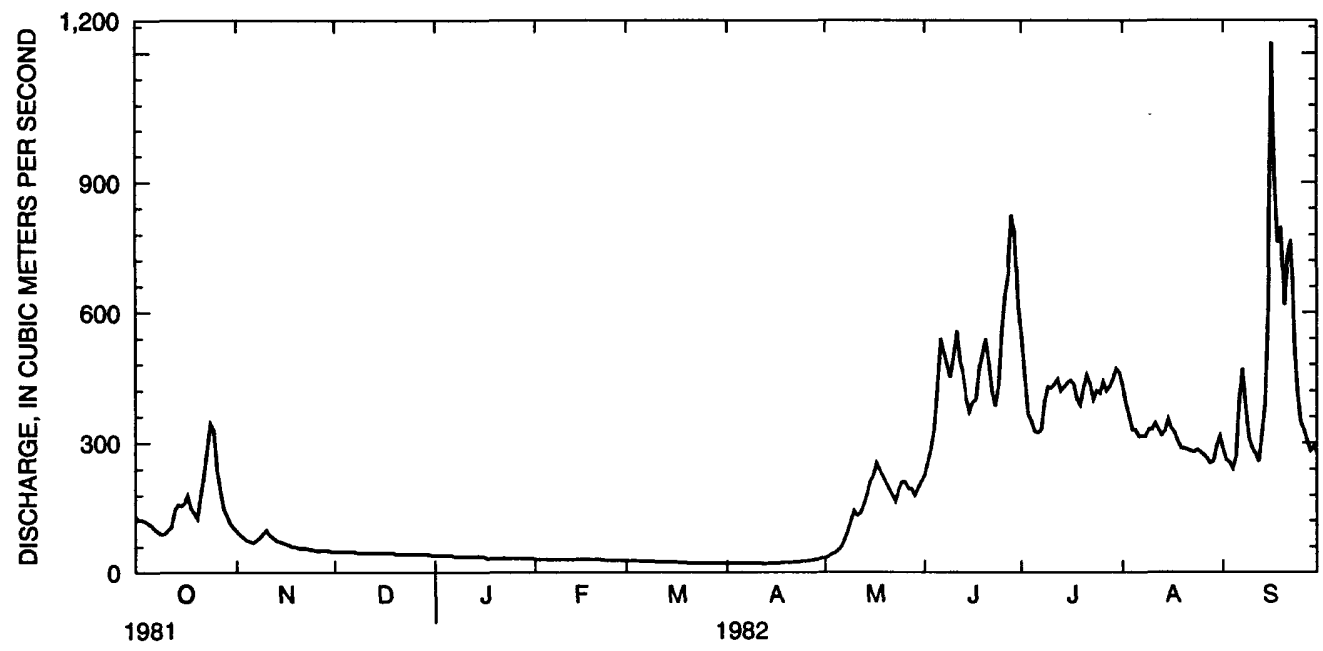

Figure 3. Mean daily discharge during the 1982 water year at USGS streamflow gaging station 15294300, Skwentna River near Skwentna, Alaska.

\section{Floods}

In 1986, heavy rain caused erosion of the banks of the Skwentna River, which destroyed two houses in Skwentna (U.S. Army Corps of Engineers, 1993). During the peak of this flood, the discharge of the Skwentna River was about 2,000 $\mathrm{m}^{3} / \mathrm{s}$ at the gaging station (Jones and Fahl, 1994). A flow of $2,000 \mathrm{~m}^{3} / \mathrm{s}$ is equalled or exceeded an average of between once every 100 years and once every 200 years based on records through 1990 (Jones and Fahl, 1994; table 6). This flood frequency, however, applies to rain and snowmelt runoff floods and is not applicable to ice-jam floods (Jones and Fahl, 1994). 
Table 6. Peak discharges of the Skwentna River for various recurrence intervals

[Discharge is in cubic meters per second; modified from Jones and Fahl (1994, p. 6)]

\begin{tabular}{|c|c|c|c|c|c|c|c|c|}
\hline $\begin{array}{l}\text { Recurrence } \\
\text { interval. . . }\end{array}$ & 2-years & 5 years & 10 years & 25 years & 50 years & 100 years & 200 years & 500 years \\
\hline Discharge ... & 940 & 1,200 & 1,350 & 1,580 & 1,760 & 1,930 & 2,190 & 2,400 \\
\hline
\end{tabular}

Ice-jam flooding occurs when river ice broken during spring thaw is transported downstream, and its downstream movement is blocked by a constriction, sandbar, or other obstruction such as a sharp meander bend. The blockage prevents ice movement and restricts water flow as the ice jam builds in thickness and length. As the water velocity slows, it produces a rise in water level or backwater effect that propagates upstream from the ice jam. When the ice jam releases, a flood wave propagates downstream. Ice-jam flooding could occur in any of the numerous meanders of the Skwentna River. The highest stage flood at Skwentna is reported to have occurred in 1953 and was caused by a downstream ice jam and backwater (U.S. Army Corps of Engineers, 1993).

\section{Ground Water}

Alluvial deposits underlying the Skwentna FAA facility are the primary aquifer in the area. Ottley (1987) reported that the water table was located between about 0.5 and $2.5 \mathrm{~m}$ below land surface at the Skwentna FAA facility. Ground water may also be present in fractured bedrock. Generally, ground water flows southward with the decline in topography, although, locally, ground-water-flow direction may vary near water bodies or impermeable bedrock. During periods of reduced runoff, ground water provides base flow to the Skwentna and Yentna Rivers. No investigations are known of the local ground-water system near the Skwentna FAA facility. However, because Skwentna is on a stream terrace between the Skwentna and Yentna Rivers, ground water is likely to be abundant.

\section{Drinking-Water Sources}

The U.S. Army Corps of Engineers (1993) reports that drinking water at Skwentna is obtained from streams and lakes and is not publicly treated. However, public facilities such as the Skwentna school have wells and most of the population is believed to obtain water from wells (appendix 2; Randy Altermatt, principal, Skwentna school, oral commun., 1995). Alternative sources of drinking water include nearby streams and lakes. However, the data are inadequate to characterize the quantity or quality of these sources. Nine surface-water samples were taken within $10 \mathrm{~km}$ of the Skwentna FAA facility during a uranium reconnaissance of the Tyonek NTMS quadrangle (Jacobsen and others, 1979). Analyses of these surface-water samples identified the amount of uranium present, concentrations of 12 additional elements, as well as basic water-quality information such as $\mathrm{pH}$ and specific conductance (Jacobsen and others, 1979). Concentrations of selected elements as well as water-quality data for these samples are summarized in table 7. 
Table 7. Water-quality data from nine surface-water samples taken within 10 kilometers of the Skwentna FAA facility near Skwentna, Alaska

[Data in micrograms per liter except where indicated; $\mu \mathrm{S} / \mathrm{cm}$, microsiemen per centimeter at $25^{\circ} \mathrm{C}$; $<$, less than;

—, property not regulated; sample designations and data from Jacobsen and others (1979)]

\begin{tabular}{lcccccccccc}
\hline \multicolumn{1}{c}{$\begin{array}{c}\text { Constituent } \\
\text { (or property) }\end{array}$} & $\begin{array}{c}\text { USEPA } \\
\text { regulation }\end{array}$ & \multicolumn{7}{c}{ Sample designation } \\
\cline { 3 - 10 } & 49801 & 49802 & 49901 & 49902 & 49938 & 49939 & 49986 & 49987 & 50056 \\
\hline Chromium (Cr) & $100^{\mathrm{b}}$ & $<25$ & $<25$ & $<25$ & $<25$ & $<25$ & $<25$ & $<25$ & $<25$ & $<25$ \\
Copper (Cu) & $1300^{\mathrm{c}}$ & 27 & 16 & 22 & 20 & 5 & 9 & 47 & 41 & 13 \\
Iron (dissolved; Fe) & $300^{\mathrm{d}}$ & 2396 & 431 & 5614 & 6014 & 5499 & 25902 & 14153 & 13054 & 546 \\
Lead (Pb) & $0.0^{\mathrm{c}}$ & $<200$ & $<200$ & $<200$ & $<200$ & $<200$ & $<200$ & $<200$ & $<200$ & $<200$ \\
Manganese (Mn) & $50^{\mathrm{d}}$ & 50 & 6 & $<25$ & $<25$ & 558 & 2146 & 1700 & 2275 & 13 \\
Nickel (Ni) & $100^{\mathrm{b}}$ & $<25$ & $<25$ & 45 & $<25$ & $<25$ & 41 & $<25$ & $<25$ & 32 \\
Zinc (Zn) & $5000^{\mathrm{d}}$ & 55 & $<50$ & $<50$ & 51 & 69 & 68 & $<50$ & $<50$ & $<50$ \\
pH (units) & $6.5-8.5^{\mathrm{d}}$ & 6.0 & 5.8 & 5.6 & 5.6 & 5.5 & 5.7 & 5.4 & 5.5 & 7.0 \\
Specific conductance & - & 14 & 8 & 22 & 307 & 27 & 167 & 164 & 138 & 16 \\
$(\mu \mathrm{S} / \mathrm{cm})$ & & & & & & & & & & \\
\hline
\end{tabular}

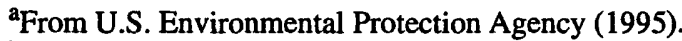

baximum contaminant level.

CMaximum contaminant level goal.

${ }^{\mathrm{d}}$ Secondary maximum contaminant level.

\section{SUMMARY}

The FAA owns and (or) operates airway support and navigation facilities at Lake Minchumina and Skwentna, Alaska. Lake Minchumina and Skwentna are remote lowland locations whose primary access is by air. Lake Minchumina is in the interior of Alaska and has a continental climate modified by the presence of Lake Minchumina. Near Lake Minchumina, Quaternary sedimentary surficial deposits overlie metamorphic bedrock. Ground water is likely the primary source of drinking water at the Lake Minchumina FAA facility and bedrock is likely the primary aquifer. Alternative sources of drinking water include Lake Minchumina and the numerous nearby streams and lakes. However, the data are inadequate to characterize the quantity or quality of these sources.

Skwentna is in south-central Alaska and has a climate that is transitional between maritime and continental. Near Skwentna, glacial and alluvial surficial deposits overlie marine sedimentary bedrock. Glacial and alluvial deposits are likely the primary aquifer. Ground water is the primary source of drinking water near Skwentna and the Skwentna FAA facility. Alternative sources of drinking water include surface-water sources. However, the data are inadequate to characterize the quantity or quality of these sources. 


\section{REFERENCES CITED}

Alaska Department of Community and Regional Affairs, 1991, Skwentna community profile: Juneau, Alaska, Municipal \& Regional Assistance Division - Community Database, variously paged.

Anderson, G.S., 1970, Hydrologic reconnaissance of the Tanana Basin, central Alaska: U.S. Geological Survey Hydrologic Investigations Atlas, HA-319, 4 sheets, scale 1:1,000,000.

Ecology and Environment, Inc., 1992a, RCRA facility investigation corrective measures study, Federal Aviation Administration, flight service station, Lake Minchumina, Alaska; Anchorage [Draft available from the Environmental Compliance Section, AAL-465, Federal Aviation Administration, Alaska Regional Office].

1992b, Environmental compliance investigation report, Skwentna FAA Station, Skwentna, Alaska: Anchorage, [Draft available from the Environmental Compliance Section, AAL-465, Federal Aviation Administration, Alaska Regional Office].

Ferrians, O.J., Jr., comp., 1965, Permafrost map of Alaska: U.S. Geological Survey Miscellaneous Geologic Investigations Map I-445, 1 sheet, scale, 1:2,500,000.

Freethey, G.W., and Scully, D.R., 1980, Water resources of the Cook Inlet Basin, Alaska: U.S. Geological Survey Hydrologic Investigations Atlas HA-620, 4 sheets, scale 1:250,000.

Hartman, C.W., and Johnson, P.R., 1984, Environmental atlas of Alaska: University of Alaska Fairbanks, Institute of Water Resources/Engineering Experiment Station, 95 p.

Holmes, C.E., and Gudgel-Holmes, D., 1988, Archaeological history and historical investigations of the Lake Minchumina airport improvements project, project no. 63605, 1987: Alaska Department of Natural Resources, Office of History and Archaeology Report Number 13, 21 p.

Hopkins, D.M., Karlstrom, T.N.V., and others, 1955, Permafrost and ground water in Alaska: U.S. Geological Survey Professional Paper 264-F, $146 \mathrm{p}$.

Jacobsen, S.I., Aamodt, P.L., and Sharp, R.R., Jr., 1979, Uranium hydrogeochemical and stream sediment reconnaissance of the Lime Hills and Tyonek NTMS quadrangles, Alaska, including concentrations of forty-three additional elements: Los Alamos Scientific Libraries, Informal Report LA-7348-MS, 224 p.

Jones, S.H., and Fahl, C.B., 1994, Magnitude and frequency of floods in Alaska and conterminous basins of Canada: U.S. Geological Survey Water-Resources Investigations Report 93-4179, 122 p.

Kodama, Y., 1981, The microclimate of a lake in a subarctic climatic region: Fairbanks, University of Alaska-Fairbanks, M.S. thesis, $72 \mathrm{p}$.

Leslie, L.D., 1989, Alaska climate summaries (2d ed.): University of Alaska Anchorage, Arctic Environmental Information and Data Center, Alaska Climate Center Technical Note No. 5.

Magoon, L.B., Adkison, W.L., and Egbert, R.M., 1976, Map showing geology, wildcat wells, tertiary plant fossil localities, K-Ar age dates, and petroleum operations, Cook Inlet area, Alaska: U.S. Geological Survey Miscellaneous Geologic Investigations Map I-1019, 3 sheets, scale 1:250,000.

Martinson, M.A., 1982, Engineering geology and soils report, Lake Minchumina airport: Alaska Department of Transportation and Public Facilities, Project No. D-27111, 6 p.

National Oceanic and Atmospheric Administration, 1993, Alaska-22 Jul 1993 to 16 Sep 1993: U.S. Department of Commerce, U.S. Government Flight Information Publication, Supplement, 288 p.

Ondra, P.J., 1988, Engineering geology and soils report, Lake Minchumina airport improvements: Alaska Department of Transportation and Public Facilities Project No. D2712/63605, 51 p.

Ottley, T., 1987, Engineering geology and soils report, Skwentna airport materials investigation: Alaska Department of Transportation and Public Facilities Project No. 56730, variously paged.

Reed, B.L., and Nelson, S.W., 1980, Geologic map of the Talkeetna quadrangle, Alaska: U.S. Geological Survey Miscellaneous Geologic Investigations Map I-1174, 1 sheet, scale 1:250,000. 
Reed, J.C., Jr., 1961, Geology of the Mount McKinley quadrangle, Alaska: U.S. Geological Survey Bulletin 1108-A, 36 p., 1 pl. in pocket.

Rieger, S., Schoephorster, D.B., and Furbush, C.E., 1979, Exploratory soil survey of Alaska: U.S. Soil Conservation Service, $213 \mathrm{p}$.

Selkregg, L., 1976, Alaska regional profiles-Southcentral region: University of Alaska, Arctic Environmental Information and Data Center, 255 p.

U.S. Army Corps of Engineers, 1993, Alaskan communities-Flood hazard data: U.S. Army Corps of Engineers, Alaska District, 335 p.

U.S. Census Bureau, 1991, Percent distribution Alaska population by sex, race, and Hispanic origin-1990 census: Alaska Department of Labor, Research, and Analysis, 3 p.

U.S. Environmental Protection Agency, 1995, Drinking-water regulations and health advisories: Washington, D.C., U.S. Environmental Protection Agency, Office of Water, May 1995, 11 p.

U.S. Geological Survey, 1983, Water resources data for Alaska, water year 1982: U.S. Geological Survey Water-Data Report AK-82-1, 363 p.

1995, Water resources data for Alaska, water year 1994: U.S. Geological Survey Water-Data Report AK-94-1, $289 \mathrm{p}$.

Viereck, L.A., and Little, E.L., Jr., 1972, Alaska trees and shrubs: U.S. Department of Agriculture, Forest Service, Agriculture Handbook No. 410, 265 p.

Wahrhaftig, C., 1965, Physiographic divisions of Alaska: U.S. Geological Survey Professional Paper 482, 52 p.

Wolfe, J.A., Hopkins, D.M., and Leopold, E.B., 1966, Tertiary stratigraphy and paleobotany of the Cook Inlet region, Alaska: U.S. Geological Survey Professional Paper 398-A, 29 p. 


\section{APPENDIX 1}

Analyses of water from three wells at the Lake Minchumina FAA facility, Alaska. 
UNITED STATES DEPARTMENT OF THE $\| \vee$,ERIOR

GEOLOGICAL SURVEY

\section{WATER ANALYSIS}

Location Minchumina I'Ai Station, Alaska

Source i:ew i:ell

Cased to ( $\mathrm{ft}$ )

Date drilled

Owner FAA

Point of coll.

County

Depth (ft) 210 Diam (in.)

Treatment

WBF

none

WL

Use Dopiestic

Temp $\left({ }^{\circ} \mathrm{F}\right)$ Appear. when coll.

Collected June I, 1959 Yield

By Station Hanager

Remarks

\begin{tabular}{|c|c|c|c|c|c|}
\hline & ppm & epm & & $\mathrm{ppm}$ & epm \\
\hline Silica $\left(\mathrm{SiO}_{2}\right)$ & 7.8 & & Bicarbonate $\left(\mathrm{HCO}_{3}\right)$ & 107 & 1.75 \\
\hline Aluminum (Al) & & & Carbonate $\left(\mathrm{CO}_{3}\right)$ & 0 & .00 \\
\hline $\begin{array}{l}\text { In sin }(\mathrm{Fe}) \text { analysed } \\
\text { Ironen }\end{array}$ & .02 & & & & \\
\hline $\begin{array}{l}\text { in sol'n when } \\
\text { ianganese }(\mathrm{M} \text { ) analysed }\end{array}$ & .09 & 0.00 & Sulfate $\left(\mathrm{SO}_{4}\right)$ & 17 & .35 \\
\hline & & & Chloride (Cl) & 2.0 & .06 \\
\hline & & & Fluoride (F) & .1 & .00 \\
\hline Calcium (Ca) & 22 & 1.10 & & & \\
\hline Magnesium (Mg) & 10 & .82 & Nitrate $\left(\mathrm{NO}_{3}\right)$ & .0 & .00 \\
\hline Sodium (Na) & 4.6 & .20 & & & \\
\hline Potassium (K) & .5 & .01 & & & \\
\hline Total & & 2.13 & \multicolumn{2}{|l|}{ Total } & 2.16 \\
\hline
\end{tabular}

\begin{tabular}{|c|c|c|c|}
\hline & ppm & & \\
\hline & & $\begin{array}{l}\text { Specific conductance } \\
\left(\text { micromhos at } 25^{\circ} \mathrm{C}\right)\end{array}$ & 206 \\
\hline $\begin{array}{l}\text { Dissolved solids: } \\
\text { Calculated }\end{array}$ & 117 & $\mathrm{pH}$ & 8.1 \\
\hline Residue on evaporation at $180^{\circ} \mathrm{C}$ & & \multirow{3}{*}{ Color } & \multirow{3}{*}{5} \\
\hline & & & \\
\hline$\frac{\mathrm{Hardness} \text { as } \mathrm{CaCO}_{3}}{\text { Noncarbonate }}$ & $\frac{96}{8}$ & & \\
\hline & & & \\
\hline & & & \\
\hline
\end{tabular}


Location MiAcHMINA. FAA Siration, ALASitA

Source NEWWELC, 2i0'DEEP

Point of coll.

Owner EAA Treatment NONE

Use Gage height (ft) Discharge (cfs)

$\operatorname{Temp}\left({ }^{\circ} \mathrm{F}\right)$

Appear. w.c. Collected 1 den 59

By Sitation MANAGE

Remarks

\begin{tabular}{ll|l|l|}
\hline & pem & epm \\
\hline $\mathrm{SiO}_{2}$ & $\mathrm{Zeg}$ &
\end{tabular}

Al

Abs. 35.0

Abs. $(A 1+F e)$

Abs. (Fe)

Fe, infol $25 \mathrm{ml}-0.02 \mathrm{y}$

Abs. 0.5

MI sid

Fe,

$\mathrm{Mn}$ inse $100 \mathrm{mi}-0.094$

2.60
Abs.

MI std

Abs. 3, 0 sid

Ml sid

$\mathrm{C}$

$-0.00$

2.80

$\mathrm{M}$

18.25

$-13.30$

$\frac{13.30}{4.95}$

ml

0

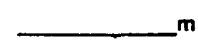

Lab. No. Col- 5464 ml

ml

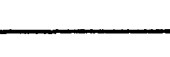

o.en

riaml 22

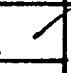

$\gamma$

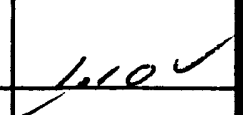

$f$

\section{Gnow tit}

$=0.01 \mathrm{mel}$

$\mathrm{HCO}_{3}$

23.25

$-17.90$

$\frac{-17.90}{5.35}$

$\mathrm{CO}_{3}$

$\mathrm{SO}_{4}$

$25 \mathrm{ml}$

17

$5.0 .0=70.5$

$+10 y=27.0$

$\mathrm{Cl} 4.40 \mathrm{50m \textrm {ml }} 3.0^{-}$

$\frac{-4.10}{0.30 \%}$

-0.302

$\frac{-0.10}{0.20}$

$\mathbf{F}$

ato

3.90

$10 \mathrm{ml}$

e.

0.06

0,35

175

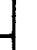


Lat. No. Col- 5464

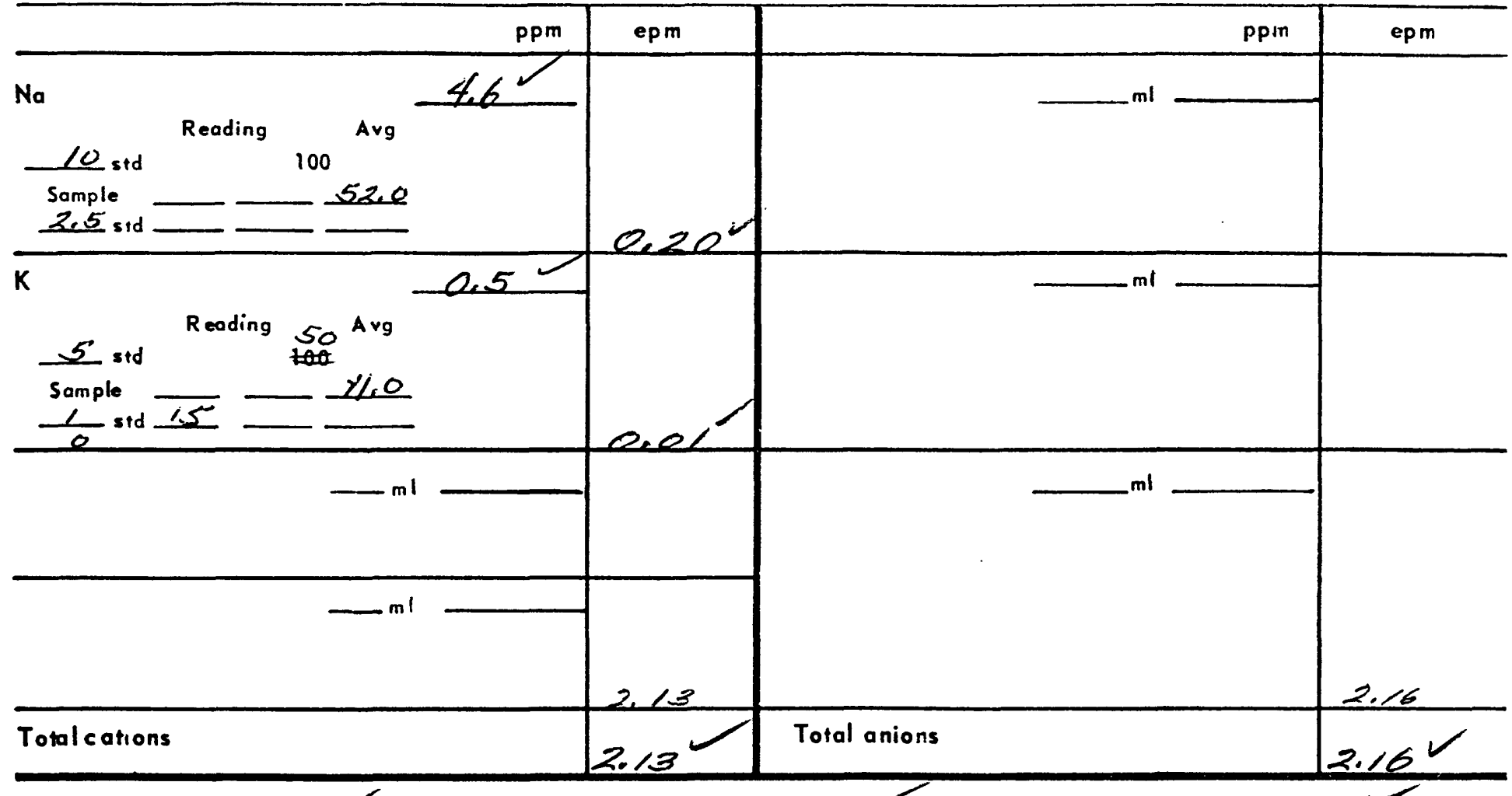

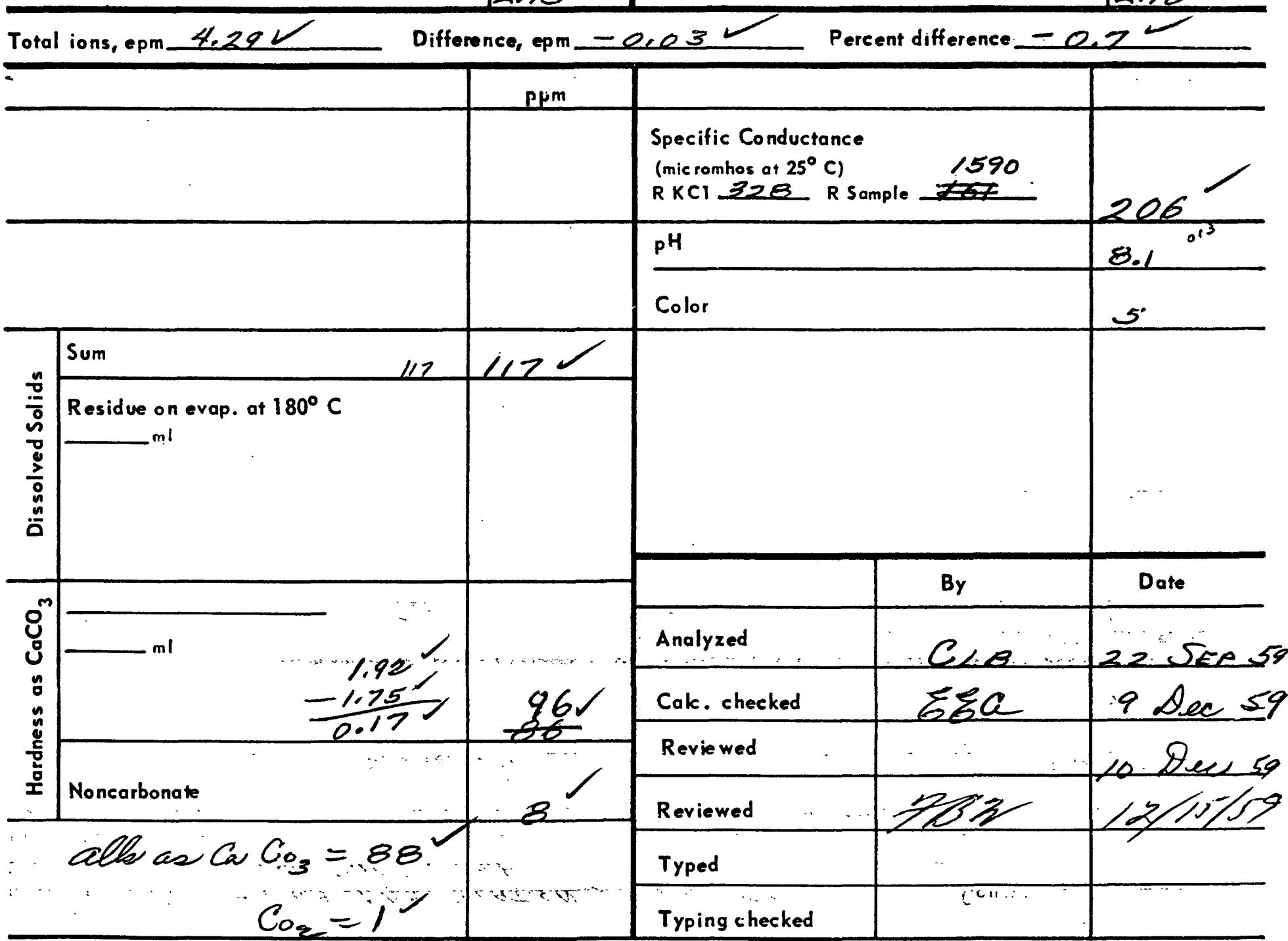


NITED STATES DEPARTMENT OF THE IN,ERIOR

GEOLOGICAL SURVEY

WATER ANALYSIS

Location At Iake lincinumina, Alaska

Source Fell in new duplex building

Cased to (ft)

Date drilled

$[\hat{4}$

Point of coll.

Owner

Treatment

WBF

WL

Use

Temp ( $\left.{ }^{\circ} \mathrm{F}\right)$

Collected

Appear. when coll.

Remarks

October 23, 1959

By

\begin{tabular}{|c|c|c|c|c|c|}
\hline & $\mathrm{ppm}$ & epm & & $\mathrm{ppm}$ & epm \\
\hline Silica $\left(\mathrm{SiO}_{2}\right)$ & 7.2 & & Bicarbonate $\left(\mathrm{HCO}_{3}\right)$ & 115 & 1.88 \\
\hline Aluminum (Al) & & & Carbonate $\left(\mathrm{CO}_{3}\right)$ & 0 & .00 \\
\hline $\begin{array}{l}\text { in sol'n when } \\
\text { Iron (Fe) analysed } \\
\end{array}$ & .03 & & & & \\
\hline Iron ( $\mathrm{Fe}$ ) Total & 6.2 & & Sulfate $\left(\mathrm{SO}_{4}\right)$ & 23 & .48 \\
\hline $\begin{array}{l}\text { in solution } \\
\text { Langanese (hin) when }\end{array}$ & .36 & 0.03 & Chloride (Cl) & 2.0 & .06 \\
\hline analysed & & & Fluoride $(F)$ & .0 & .00 \\
\hline Calcium (Ca) & 23 & 1.15 & & & \\
\hline Magnesium (Mg) & 12 & .99 & Nitrate $\left(\mathrm{NO}_{3}\right)$ & .0 & .00 \\
\hline Sodium (Na) & 4.4 & .19 & & & \\
\hline Potassium (K) & .7 & .02 & & & \\
\hline Total & & 2.38 & Total & & 2.42 \\
\hline
\end{tabular}

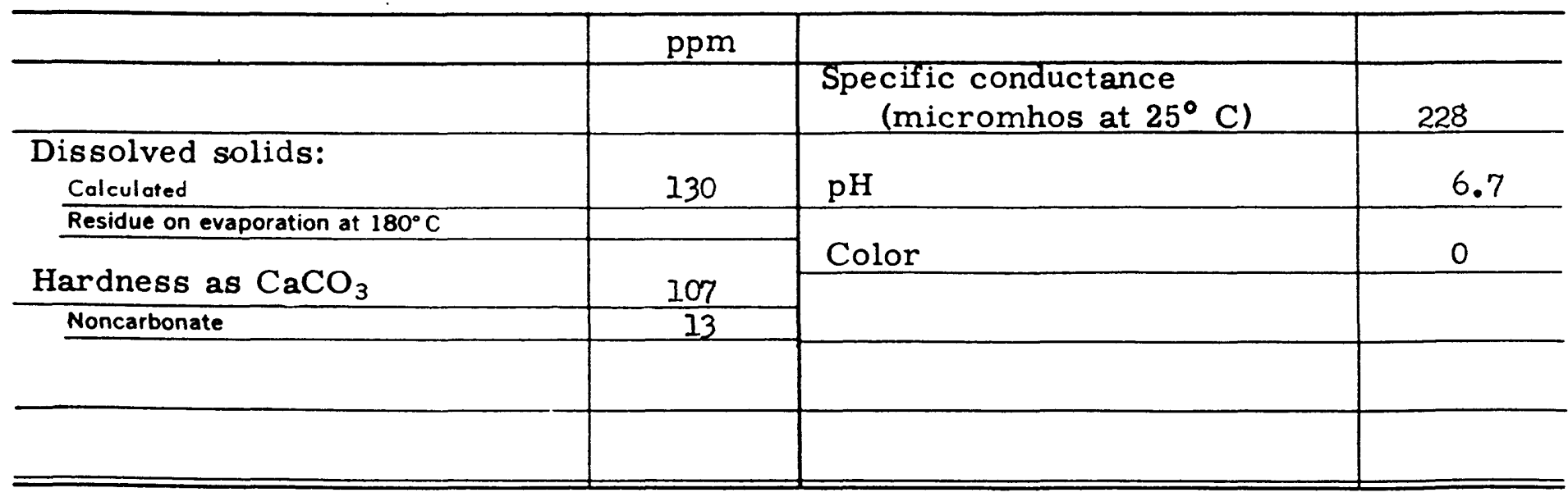




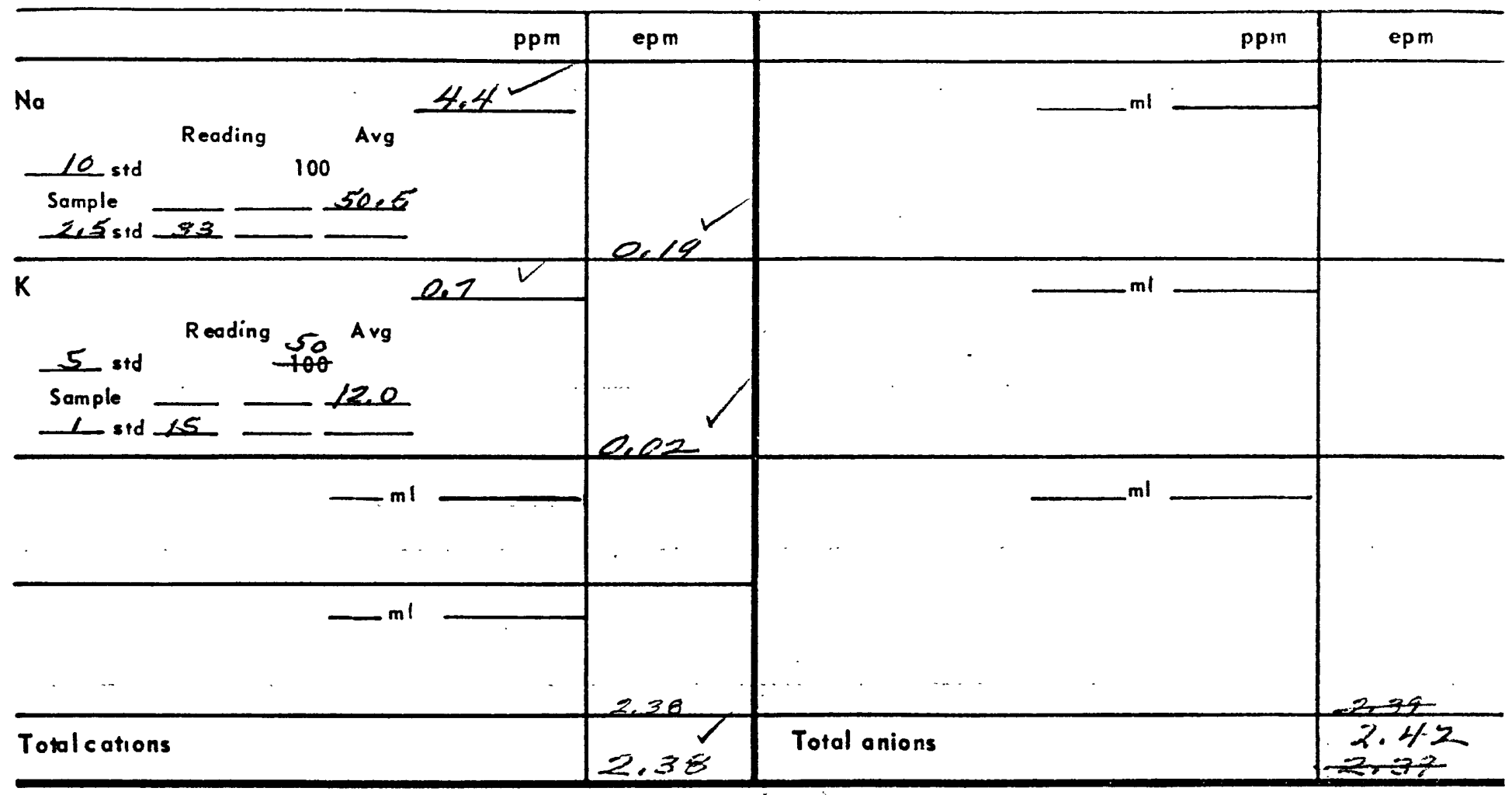

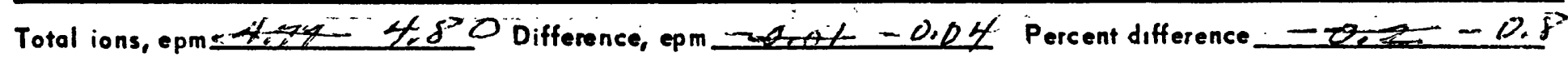

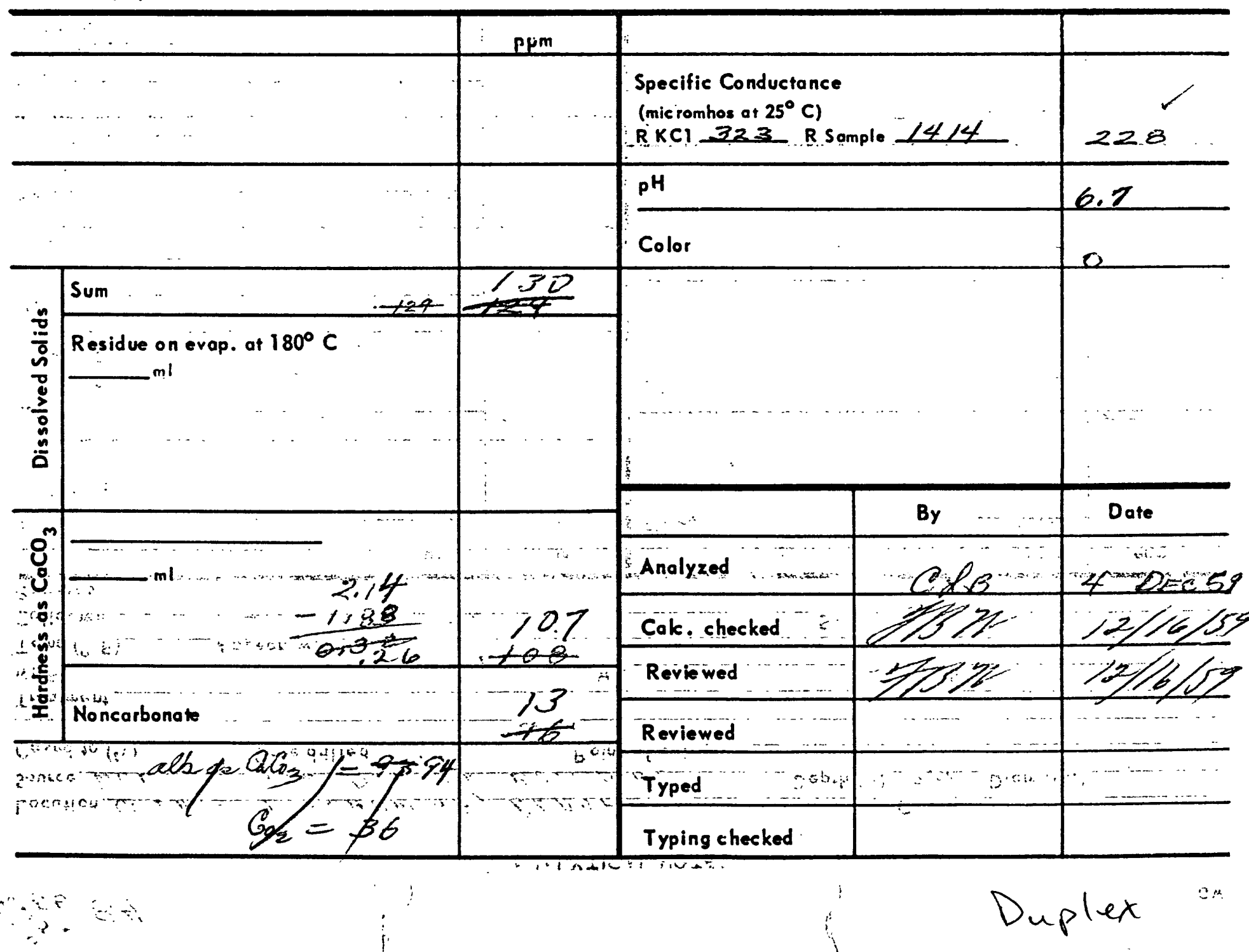


WATER ANALYSIS

Location Linchuritina Fki Station, Alaska

Source iell no. 3

Cased to (ft)

Date drilled

Owner Point of coll.
Depth $(\mathrm{ft})$
County
Diam (in.) 4

Treatment

WBF

Temp $\left({ }^{\circ} \mathrm{F}\right)$
Collected $12 / 11 / 50$ at $10: 30$ am

WL $\quad 170 \mathrm{ft}$

Use

Remarks

\begin{tabular}{|c|c|c|c|c|c|}
\hline & ppm & epm & & $\mathrm{ppm}$ & epm \\
\hline Silica $\left(\mathrm{SiO}_{2}\right)$ & 7.8 & & Bicarbonate $\left(\mathrm{HCO}_{3}\right)$ & 106 & 1.74 \\
\hline Aluminum (AI) & & & Carbonate $\left(\mathrm{CO}_{3}\right)$ & 0 & .00 \\
\hline $\begin{array}{l}\text { in sol'n when } \\
\text { Iron (Fe) analysed }\end{array}$ & .10 & & & & \\
\hline \multirow[t]{3}{*}{ lianganese $(\operatorname{lin})$} & .46 & 0.03 & Sulfate $\left(\mathrm{SO}_{4}\right)$ & 20 & .42 \\
\hline & & & Chloride (Cl) & 2.0 & .01 \\
\hline & & & Fluoride (F) & .2 & .01 \\
\hline Calcium (Ca) & 21 & 1.05 & & & \\
\hline Magnesium (Mg) & 11 & .90 & Nitrate $\left(\mathrm{NO}_{3}\right)$ & .2 & .00 \\
\hline Sodium (Na) & 6.0 & .26 & & & \\
\hline Potassium (K) & .7 & .02 & & & \\
\hline Total & & 2.26 & Total & & 2.23 \\
\hline
\end{tabular}

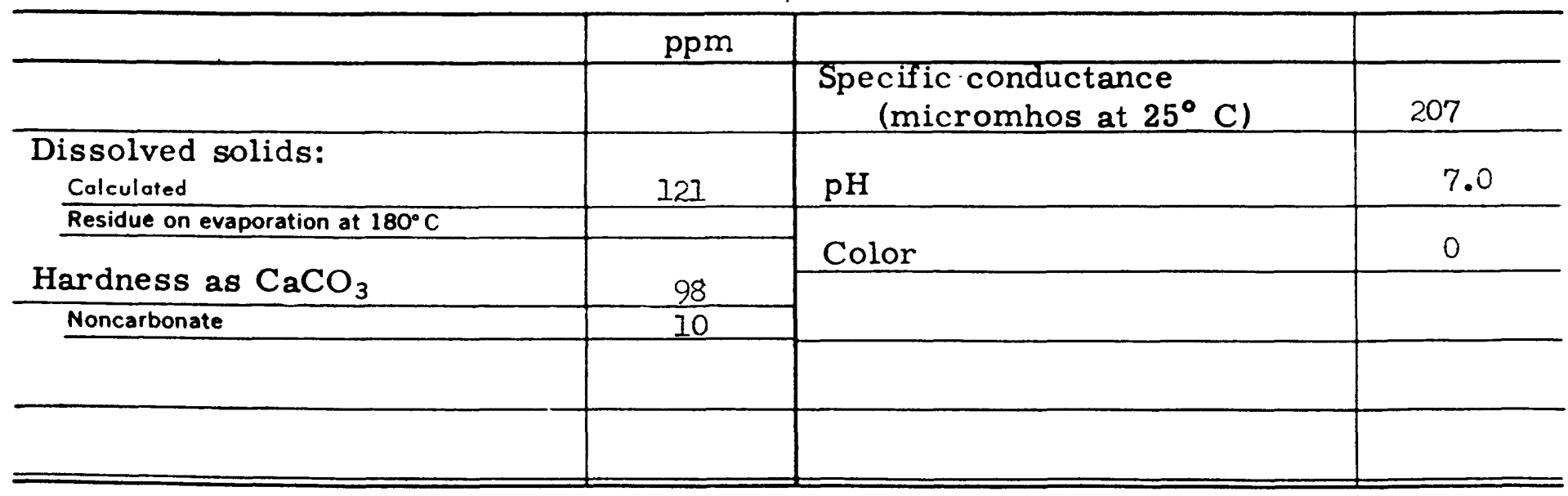

Yield By 


\section{Plirelicirelidi- ANALYTICAL NOTES}

Location FAA, Minchuming, Alaska

Source

WeII No. 3

Cased to $(f t)$

Dote drilled

Point of coll.

County

Depth $(f+1) 210$ Diam (itit) 4

Treatment

WBF

$\operatorname{Temp}\left(^{\circ} \mathrm{F}\right)$

Collected

Appear. w.c

WL

Use

Owner

Remarks Depth to water $170 \mathrm{ft}$.

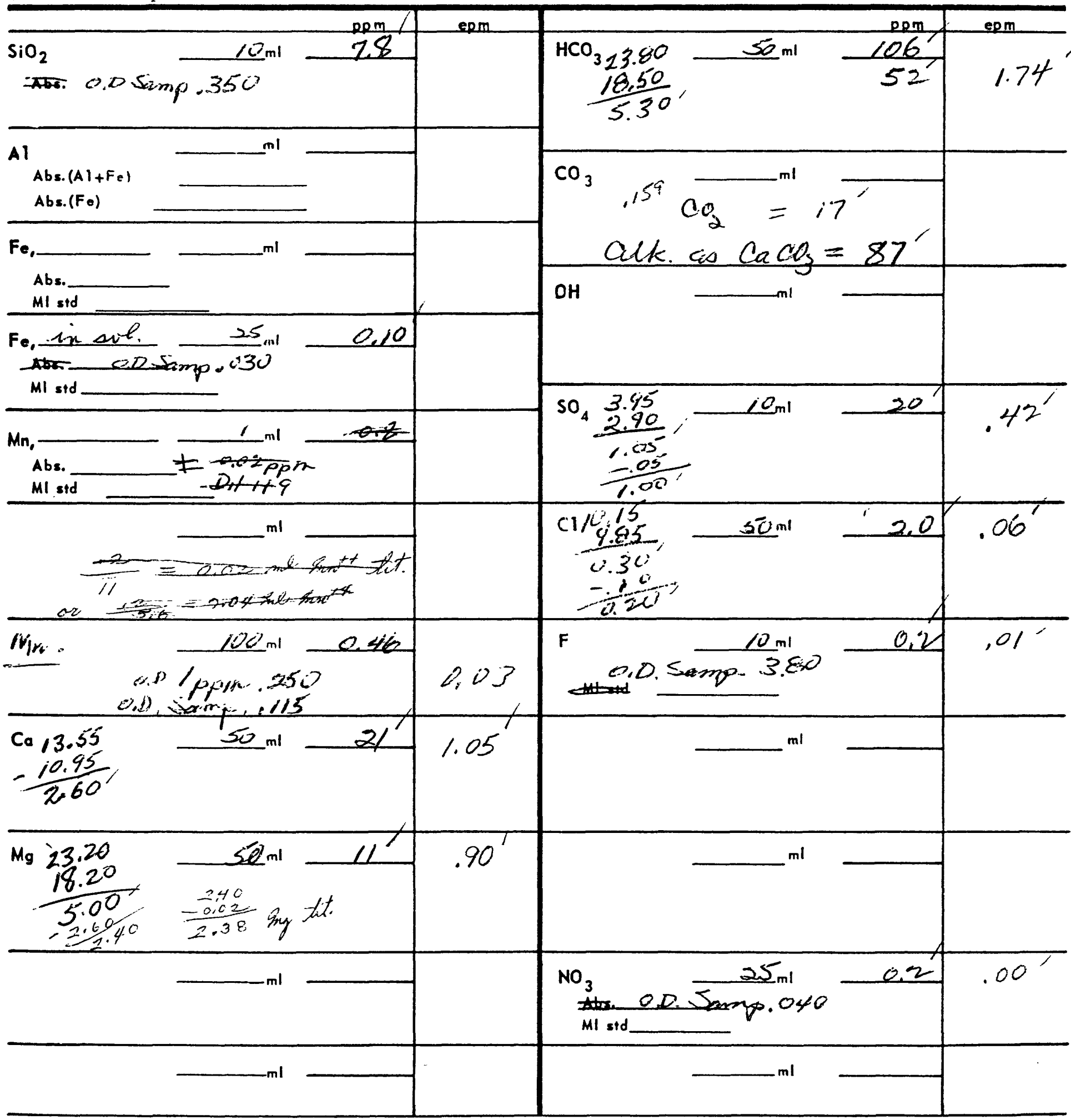

Lab. No. Col-, 5624

Field No.

$R$ No.

No. 3 
Lab. No. Col. 5624

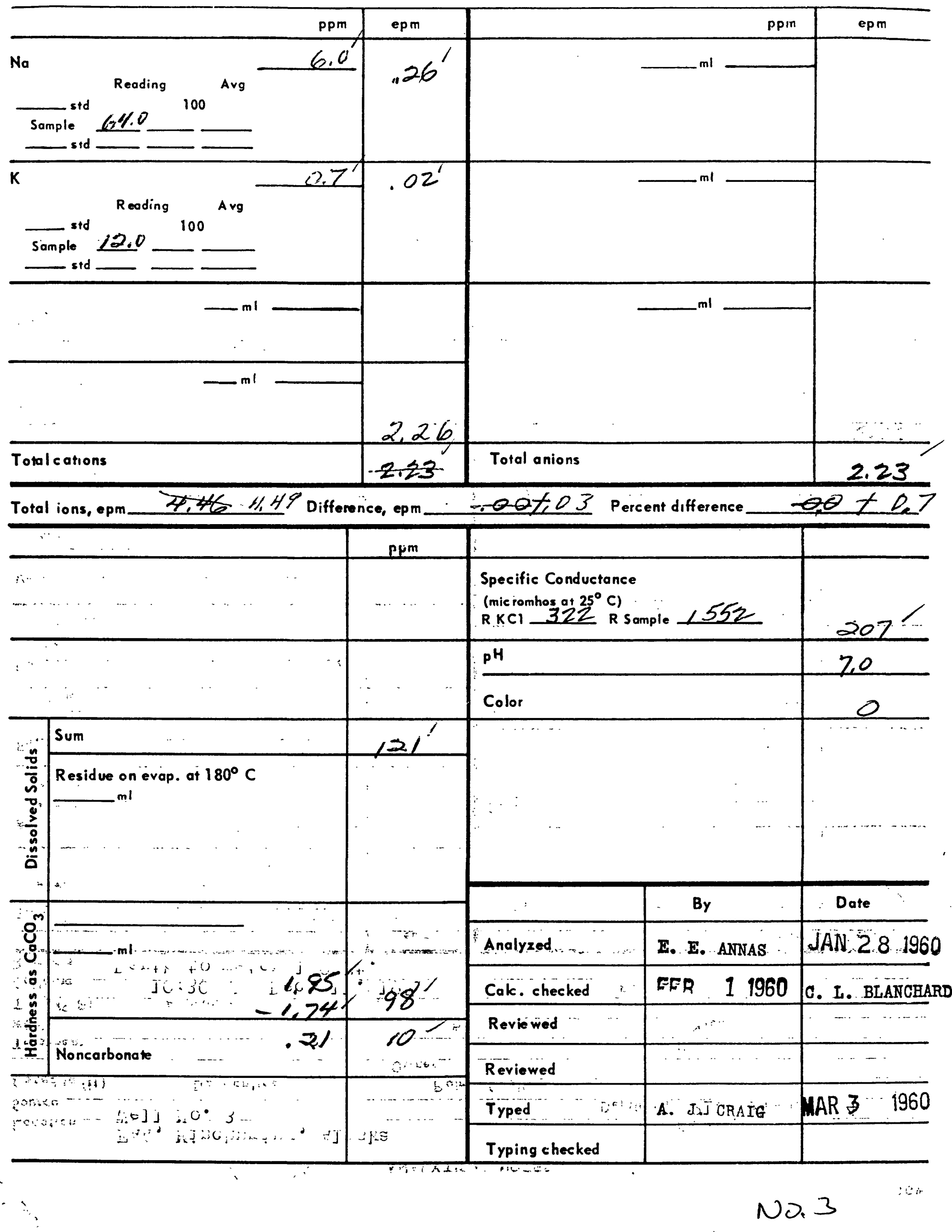




\section{APPENDIX 2}

Water record for a well at the Skwentna school 


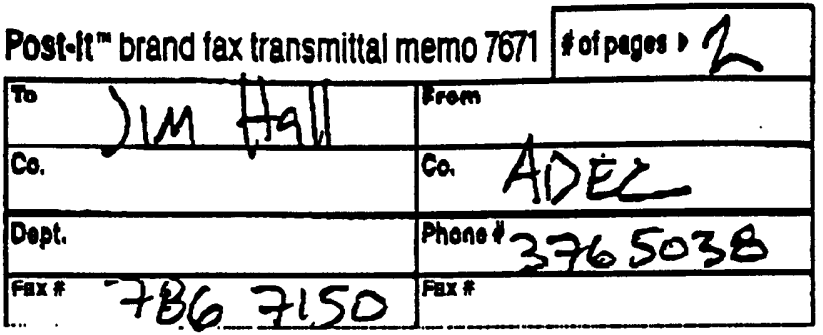

WATER WELW RECORD

STATE OF ALASKA

DEPARTMENT OF NATURAL RESOURES

Division of sealogicol a Geophysieal Survays

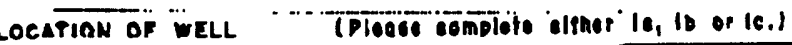

Drilitine oopralt kn.

A.D.L. No.

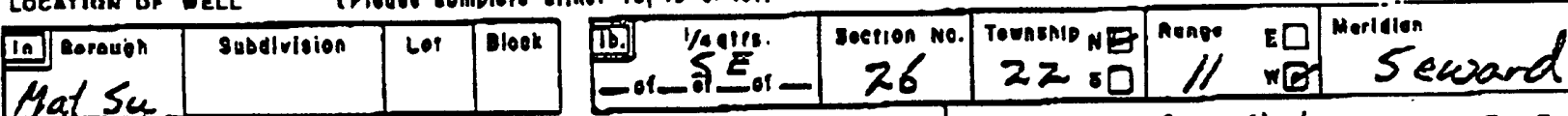

18. DISTANCE ANO OIRECTION FROM ROAD IKTERSECTIONS

Skiventra Schoof, Near Rive-

street acerces end ar.es of well beection

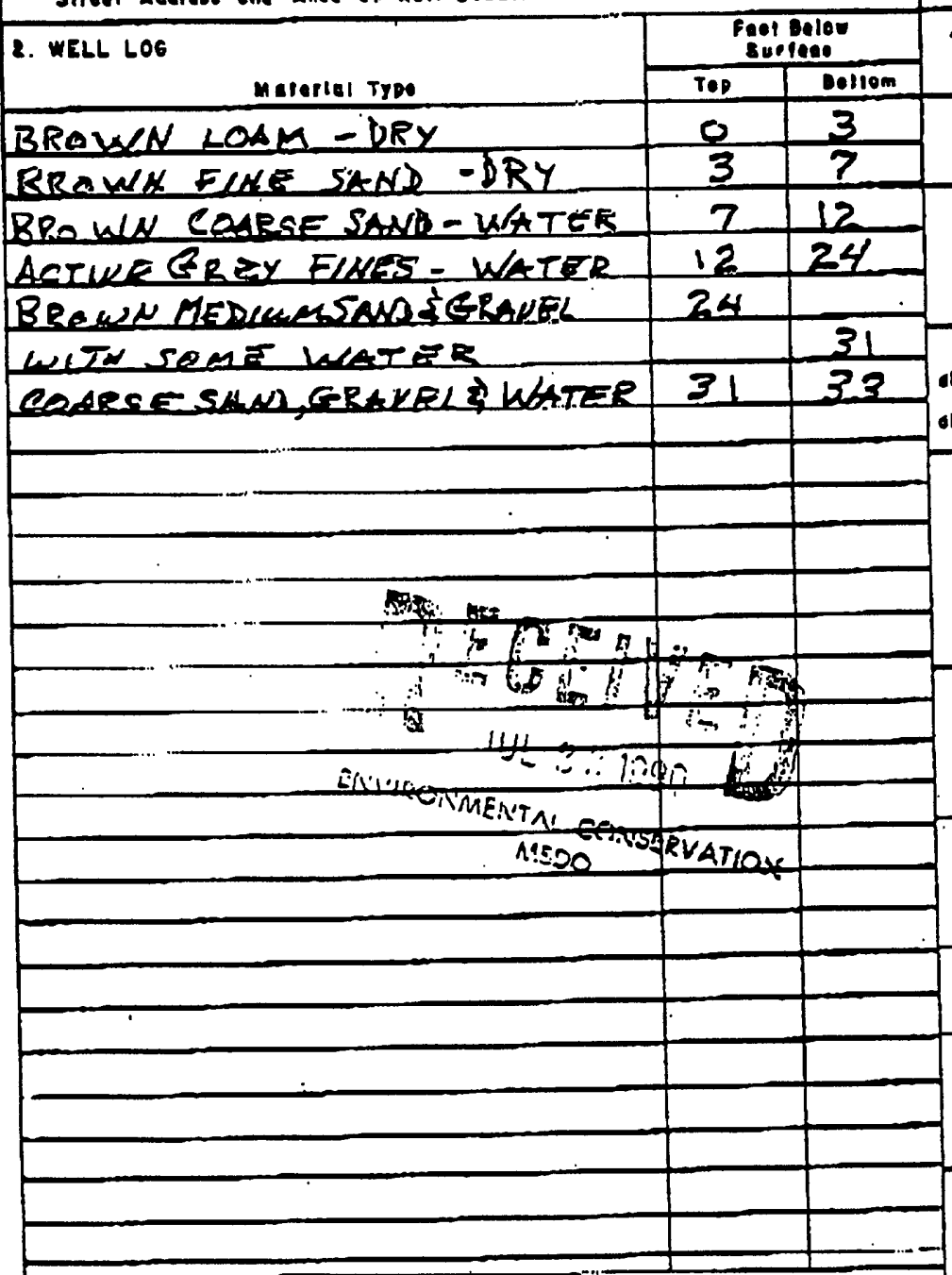

10. WATER WELL CONTRAGTOR'S GERTIFICAIION:
3. owner or well Matanderke-Sugita a

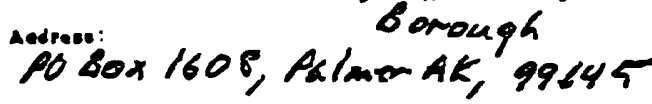

4. WELL ORPTH: (OINel)

- DATE OF COMPLETIOK

33 .

$26-06-90$

- Eacabie cons $\square$ netary $\square$ oplven $\square$ Due

$\square$ auser $\square$ Jerred $\square$ bopes $\square$ omer:

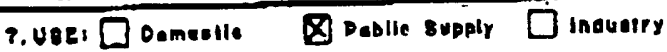

$\square$ irrlocesen $\square$ Reeneros. $\square$ cemmorieal

$\square$ Toet well $\square$ oinee:

- casinar $\square$ Throuces $Q$ wolese

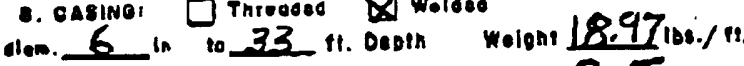

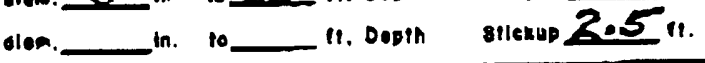

- FINISK OF WELL:

slor/moon siso: ___ Loneth:

Sot between ___ and ${ }^{\text {it. }}$

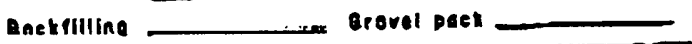

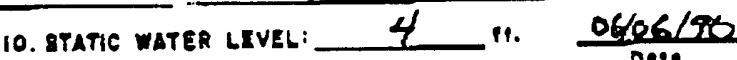

$\square$ apove or $\square$ selow lene eurtoes Date

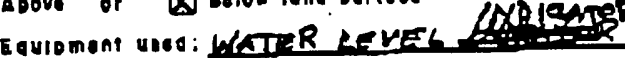

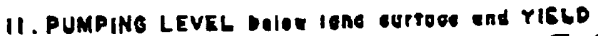

14 "1. ofrep 12 nr. oundine $17-6$ o.p.m.

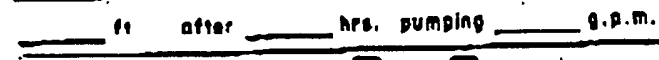

le.eroutine woll olouted: $\square$ ver 8 No

Molertel: $\square$ moet cemant $\square$ ornor:

13. Dumpi (If exolledie) Ho

Leneth of Deep Plpo

i1. oopselly

ouden. $\square$ der $\square$ oenirifleal $\square$ oiner

IA. REMARKa:

SATA BENTONITEN CASING 4 TO 5

DISTEIBLTED ARONO LUREACE

18. Woter Tomostofure —- $\square F \quad \square c$

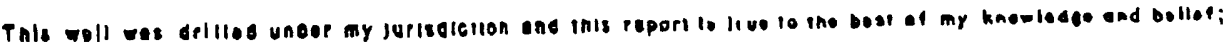

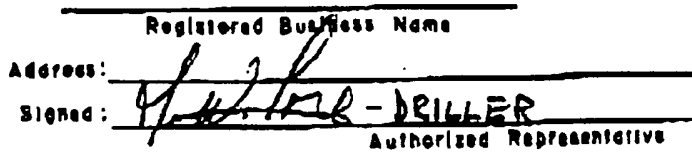

Contract Llconas Number

nate: $06-09-90$ 